\title{
Madde Güçlük İndeksi ve Madde Ayırt Edicilik İndeksine Dayalı Çeldirici Analizi
}

\author{
Distractor Analysis Based on Item Difficulty Index and Item Discrimination Index
}

\author{
Burcu HASANÇEBİ*1,a , Yüksel TERZİ',b ${ }^{2}$ Zafer KÜÇÜK ${ }^{1, c}$ \\ ${ }^{1}$ Karadeniz Teknik Üniversitesi, Fen Fakültesi, İstatistik ve Bilgisayar Bilimleri Bölümü, 61080, Trabzon \\ ${ }^{2}$ Ondokuz Mayıs Üniversitesi, Fen Edebiyat Fakültesi, İstatistik Bölümü, 55139, Samsun
}

• Geliş tarihi / Received: 04.09.2019 • • Düzeltilerek geliş tarihi / Received in revised form: 12.11.2019 • Kabul tarihi / Accepted: 26.11 .2019

\begin{abstract}
$\ddot{O} z$
Çoktan seçmeli bir maddenin ölçme aracı içerisindeki performansı belirlenirken incelenmesi gereken en önemli unsurlardan biri de çeldiricilerin etkinliğidir. Etkin çeldiricilerle oluşturulmuş maddelerin performansları daha yüksek olmaktadır. Bu noktada çeldiricilerin hazırlanma süreci de etkili bir rol oynamaktadır. Güçlü ve etkin bir çeldiricinin doğru cevapla ilgili herhangi bir bilgi taşımaması dikkat edilmesi gereken en önemli hususlardandır. Kaliteli maddelerden oluşan bir ölçme aracında cevaplayıcıların çeldiricileri neden seçtiğini araştırmak madde analiz sürecinin önemli bir kısmını oluşturmaktadır. Bilinen madde analizi sürecinde madde istatistikleri hesaplanırken yanlış cevap seçenekleri yani çeldiriciler hesaplamaya dahil edilmemektedir. Çeldirici analizinde ise madde analizinde hesaba dahil edilmeyen bu yanlış seçeneklerinin gücü araştırılıp bu seçeneklerin kalitesi ile ilgili yorumlar yapılmaktadır. Böylelikle ilgilenilen maddenin ölçme aracı içinde nasıl çalıştığı ile ilgili fikir sahibi olmak mümkündür. Bu çalışmada Karadeniz Teknik Üniversitesi İktisadi ve İdari Bilimler Fakültesi Ekonometri Bölümü öğrencilerine İstatistik Okuryazarlık Testi uygulanmış ve test kapsamındaki maddeler için çeldirici analizi yapılmıştır. Analizler R yazılımı yardımıyla yapılmıştır. Elde edilen sonuçlardan hareketle maddelerdeki çeldiricilerin etkin ve güçlü çeldiriciler olup olmadıkları ile ilgili yorumlar yapılmıştır.
\end{abstract}

Anahtar kelimeler: Çeldirici, Madde, Madde İstatistikleri, Ölçme Aracı

\begin{abstract}
One of the most important factors that should be examined when determining the performance of a multiple-choice item in the measuring instrument is the effectiveness of distractors. The performance of the items formed with effective distractors is higher. At this point, the process of preparation of distractors also plays an effective role. It is important to note that a strong and effective distractor does not carry any information about the correct answer. Investigating the reason why respondents chose distractors in a measuring instrument consisting of quality items is an important part of the item analysis process. When calculating item statistics during the known item analysis process, wrong answer options, i.e. distractors, are not included in the calculation. In distractor analysis, the power of these false answer options, which are not included in item analysis, is investigated and comments are made on the quality of these options. Thus, it is possible to have an idea of how the item of interest works in the measuring instrument. In this study, Statistical Literacy Test was applied to the students of the Department of Econometrics, Faculty of Economics and Administrative Sciences, Karadeniz Technical University, and distractor analysis was conducted for the items covered by the test. The analyzes were performed with the help of $R$ software. Based on the results obtained, comments were made about whether the distractors in the items were effective and strong.
\end{abstract}

Keywords: Distractor, Item, Item Analysis, Measuring Instrument

\footnotetext{
$*^{\mathrm{a}}$ Burcu HASANÇEBİ; burcuhsncbgmail.com, Tel: (0543) 27337 39, orcid.org/0000-0001-8830-0144

${ }^{\mathrm{b}}$ orcid.org/0000-0002-6265-542X $\quad{ }^{\mathrm{c}}$ orcid.org/0000-0001-8083-2429
} 


\section{Giriş}

Bir testin ölçülebilen yani puanlanabilen en küçük bileşenine madde denir (Turgut, 1977). Madde, ölçme teorisinde her bir soru için kullanılan bir terimdir. Bir ölçme aracının kaliteli olabilmesi, onu oluşturan maddelerin kaliteli olmasına bağlidır. Yani, testin özellikleri, testi oluşturan maddelerin özelliklerine bağlı olarak değişir.

Madde analizi, cevaplayıcıların ölçme aracındaki maddelere verdikleri tepkileri ölçerek, maddeler ile ilgili yorumda bulunmaya yarayan bir süreçtir. Ayrıca, elde edilen sonuçlara dayanarak, maddenin ölçülmek istenen özelliği ölçüp ölçmediğinin belirlenmesi, eğer beklenen şekilde performans göstermiyorsa bunun nedenlerinin incelenmesi ve amacina uygun hizmet edebilecek şekle getirilmesi sürecine de madde analizi denir (DeVellis, 2006; De Grutijter ve Van der Kamp, 2008; Allen, 2012; Tomak, 2013). Bu süreçte, maddelerin niteliğini belirten bazı indeksler hesaplanır. Bu indeksler yardımıyla maddeler için çeşitli yorumlarda bulunulur. Madde analizini, güçlük indeksi, ayırt edicilik indeksi ve çeldirici analizinden oluşan üç ayaklı bir sisteme benzetmek mümkündür.

Madde analizinin yapılmasındaki amaçlardan ilki maddelerin güvenilirliğini ve geçerliliğini denetlemektir. Böylelikle, ölçülmek istenen örtük özellik için güvenilirliği ve geçerliliği yüksek bir ölçme aracı elde edilebilir. Ancak, ölçme aracının sadece geçerlilik ve güvenilirliği madde analizi için yeterli bilgileri içermez. Güvenilirlik ve geçerliliğe ek olarak, maddelerin güçlük ve ayırt edicilik derecelerinin belirlenmesi ile çeldiricilerin iyi çalışıp çalışmadığının belirlenmesi de madde analiz sürecinin içerisinde yer alan öğelerdir. Madde analizi sonucunda elde edilen madde istatistiklerinden yola çıkarak, ölçekteki her bir maddenin performans1 ile ilgili yorumlarda bulunulabilir. Ayrıca, madde analizi yardımıyla ölçme yapılan grup ile ölçme aracının birbirine olan uyumu konusunda da bir yargida bulunulabilir. Beklendiği gibi hassas, duyarlı ve objektif sonuçlara ulaşabilmek için ölçme aracı ile ölçülen grubun birbirine uyumu oldukça önemlidir.

Literatüre bakıldığında, madde analizi sürecinde madde istatistiklerini hesaplamak için çeşitli yöntemler mevcuttur. $\mathrm{Bu}$ yöntemlerden en yaygın kullanılanlar; Henryson Yöntemi ve Basit
Yöntem'dir. Bu iki madde analizi yönteminin birbirlerinden ayrıldığı temel nokta, hesaplamalarda kullanılan ölçme sayıları yani, hesaplamaya dahil edilen örnek sayısıdır. Henryson Yönteminde, ölçmeye dahil edilen tüm yanıtlayıcılar kullanılırken, Basit Yöntemde tüm yanıtlayıcıların toplam puanlarından en başarılı $\% 27$ 'lik üst ve en başarısız \%27'lik alt grup belirlenerek, kitlenin \%54'lük kısmı kullanılır. Henryson Yöntemi küçük örneklerde bile güvenilir sonuçlar vermektedir.

Henryson Yöntemine göre, madde güçlük indeksi, maddeyi doğru cevaplayanların tüm cevaplayıcı sayısına oranıdır. Oranlama yapıldığında sınıfın yüzde kaçının soruyu doğru yanıtladığı görülür. $\mathrm{Bu}$ indeks 0 ile 1 arasında değerler alabilir. Güçlük indeksi 0'a yaklaştıkça maddenin zor bir madde, 1'e yaklaştıkça maddenin kolay bir madde olduğu yorumu yapılabilir. Güçlük indeksi,

$P=\frac{N_{a}}{N}$

biçiminde hesaplanır. Burada,

$N_{a}$ : Doğru yanıtlayan kişi sayısı

$N$ : Tüm cevaplayıcıların sayısıdır.

Güçlük indeksi, maddenin ölçme aracını alan cevaplayıcıya ne denli zor veya kolay geldiğini gösterir. Maddenin hitap ettiği en iyi örtük özellik düzeyidir. Genellikle güçlük indeksi değerinin 0.50 olması beklenir. Ancak, ölçme arac1 kapsamındaki tüm maddeler güçlük indeksleri 0.50 olarak hazırlanmaz. Bu tercih edilmeyen bir durumdur. Bunun yerine ölçme aracı içerisine zor, kolay ve orta güçlükte maddeler serpiştirilmelidir. Buradan hareketle testin ortalama güçlüğünün 0.50 olması ideal bir sonuçtur. Ölçme aracındaki maddelerin güçlük dağılımlarının da normal olması beklenmektedir. Orta güçlük düzeyindeki maddelerden oluşan ölçme araçlarının güvenilirlik düzeyi daha yüksek bulunurken, çok kolay ya da zor maddelerden oluşan testlerin güvenilirlik düzeyleri düşük bulunur.

Basit Yönteme göre güçlük indeksinin hesaplanabilmesi için alt ve üst grupların belirlenmesi gerekir. $\mathrm{Bu}$ yöntemde, öncelikle, ölçme aracindan elde edilen toplam puanlar en yüksekten düşüğe doğru sıralanır. Başarısı en yüksek olan ve başarısı en düşük olan cevaplayıcıların \%27'si alınarak alt ve üst gruplar belirlenir. Ortada kalan \%46'llk kesim hesaplamaya dahil edilmez. Buradan hareketle madde güçlük indeksi, 
$p_{i}=\frac{\begin{array}{c}\text { Maddeyi üst grupta } \\ \text { doğru cevaplayanların sayısı }\end{array}{ }^{\text {Moğru cevaplayanlarıta sayısı }}}{\text { üst gruptaki }}$

biçiminde hesaplanır.

İki yöntemden herhangi birinden elde edilen indeks değerine göre maddenin güçlügüü ile ilgili Tablo 1. yardımıyla yorum yapılabilmektedir.

Tablo 1. Madde güçlük indeksine bağlı madde değerlendirmesi

\begin{tabular}{|c|c|}
\hline $\begin{array}{c}\text { Madde Güçlük } \\
\text { Indeksi }\end{array}$ & $\begin{array}{c}\text { Maddenin } \\
\text { Değerlendirilmesi }\end{array}$ \\
\hline 0.29 ve altında & Zor \\
\hline $0.30-0.49$ & Orta güçlükte \\
\hline $0.50-0.69$ & Kolay \\
\hline $0.70-1$ & Çok kolay \\
\hline
\end{tabular}

Ayırt edicilik indeksi, bir maddenin başarı düzeyi yüksek cevaplayıcılar ile düşük cevaplayıcıları ayırt etme derecesidir yani, ilgili maddenin bilenle bilmeyeni birbirinden ayırabilme ölçüsüdür. Ayırt edicilik, maddenin geçerliliği ile ilgili bir indekstir. Ayırt edicilik indeksi, -1 ile +1 arasında değer alır. İndeksin 0'a yaklaşması durumunda, ilgili maddenin alt ve üst grubu ayırt ediciliği düşük, 1'e yaklaşması durumunda ise maddenin alt ve üst grubu ayırt ediciliği yüksektir biçiminde yorum yapılabilir. İndeksin pozitif olması, maddenin doğru cevaplanma oranının üst grupta yüksek olduğunu, negatif olması ise maddenin doğru cevaplanma oranının alt grupta yüksek olduğunu gösterir. Ayırıcılı̆̆ı negatif olarak belirlenmiş bir madde testten hemen çıarilmaz. Öncelikle bu durumun maddedeki bir belirsizlik ya da cevap anahtarındaki yanlışlık gibi nedenlerden kaynaklanabileceği düşünülmelidir. İlgili yanlışlık düzeltilirse indeks pozitife dönebilir.

Madde ayırt edicilik indeksi bir maddenin içinde bulunduğu testle arasındaki korelasyona denir (Tekin, 1977). Henryson Yöntemi ile ayırt edicilik indeksi hesaplamaları, korelasyon katsayılarından yararlanarak yapılır (Baykul, 2000). Buradan hareketle, Henryson yöntemine göre ayırt edicilik indeksi,

$r_{j x}=\frac{\bar{X}(d)-\bar{X}}{S_{x}} \sqrt{\frac{p_{j}}{q_{j}}}$

biçiminde hesaplanır. Burada,

$\bar{X}(d)$ : Maddeye doğru tepki veren cevaplayıcıların ham puanlarının ortalaması

$\bar{X}$ : Bütün cevaplayıcıların ham puanlarının aritmetik ortalamas1
$S_{x}$ : Test puanlarının standart sapması

$p_{j}$ : Madde güçlüğü

$q_{j}: 1-q_{j}$ dir.

Basit Yönteme göre ayırt edicilik indeksi hesaplanırken, yöntem gereği yanıtlayıcılar alt ve üst grup olarak ikiye ayrilır. Bu yöntemde, öncelikle ölçme aracından elde edilen sonuçlara göre toplam puanlar hesaplanır ve en yüksekten düşüğe doğru sıralanır. Başarısı en yüksek olan $\% 27$ 'lik grup üst grup, başarısı en düşük olan $\% 27$ 'lik grup alt grup olarak alınır. Geriye kalan $\% 46$ 'lık grup hesaplamanın dışında tutulur. Buradan hareketle madde güçlük indeksi,

$a_{i}=\frac{\begin{array}{c}\text { üst grupta doğru } \\ \text { cevaplayan sayısı cevaplayan sayıst }\end{array}}{\text { grupların herhangi birindeki }}$

biçiminde hesaplanır.

İki yöntemin herhangi birinden elde edilmiş ayırt edicilik indeksi değerine göre maddenin ayırıcılığı ile ilgili Tablo 2. yardımıla yorum yapılabilmektedir.

Tablo 1. Madde ayırt edicilik indeksine bağl1 maddenin değerlendirilmesi

\begin{tabular}{|c|c|}
\hline $\begin{array}{c}\text { Madde Ayırt Edicilik } \\
\text { Indeksi }\end{array}$ & $\begin{array}{c}\text { Maddenin } \\
\text { Değerlendirilmesi }\end{array}$ \\
\hline 0.40 ve daha büyük & Çok iyi madde \\
\hline $0.30-0.39$ & $\begin{array}{c}\text { Oldukça iyi ama yine de } \\
\text { geliştirilebilir }\end{array}$ \\
\hline $0.20-0.29$ & $\begin{array}{c}\text { Düzeltilmesi ve } \\
\text { geliştirilmesi gerekir } \\
\text { Çok zayıf mutlaka } \\
\text { çıarılmalı }\end{array}$ \\
\hline 0.19 ve daha küçük & \\
\hline
\end{tabular}

Literatüre bakıldığında, özellikle çoktan seçmeli olarak hazırlanan ölçme araçları için birçok çalışma görmek mümkündür. Ancak, çoktan seçmeli test tipinin özellikleri, avantajları ve hazırlanışı hakkında çalışmalar mevcut olsa da seçenek analizi ile ilgili yeterli miktarda çalışma olmadığ1 görülmektedir. Buradan hareketle bu çalışma çeldirici seçenek analizi için bu eksiklikten doğan ihtiyaçla yapılmıştır.

Çoktan seçmeli testler; ölçme ve değerlendirme alanında kullanılan en başarılı yöntemlerden biridir. Literatürde Kelly (1914), bu tip çoktan seçmeli testlerin kurucusu olarak bilinir. Buna ek olarak Kelly (1916) da, Kansas Sessiz Okuma testini literatüre kazandırmıştır. Kelly'nin sözü 
edilen çalışması literatüre kazandırılıncaya kadar, açık uçlu ölçme araçları kullanılmaktaydı. Kansas Sessiz Okuma Testi'nde ise cevaplayıcilar, madde içerisinde kendilerine sunulmuş seçeneklerden birini işaretlemek zorundaydılar. Bu tip bir ölçme aracı, uygulanan açık uçlu ölçme araçlarından yapıs1 itibariyle farkl11ı göstermekteydi. Kelly'nin ortaya koyduğu sisteme uygun olarak, Terman 1926 yılında, Alfred Binet ve çalışma arkadaşı Theodore Simon tarafindan 1905 yılında oluşturulan Stanford-Binet Zeka Testi'ni geliştirerek literatüre kazandırmıştır. StanfordBinet Zeka Testi, çocuklarda zihinsel geriliği saptamaya yönelik bir testtir. Lewis Madison Terman ise bu testi Kelly'nin geliştirdiği sisteme uyarlamıştır. 1934 yılında ise IBM tarafindan geliştirilen ilk optik okuyucu sistemi sayesinde, çoktan seçmeli testlerin değerlendirme aşamaları kolaylaşmış ve böylelikle çoktan seçmeli ve büyük ölçekli testler oluşturulmaya başlanmıştır. Günümüzde bu tip çoktan seçmeli testlerin kullanımı PISA ya da ÖSYM'nin yaptığ sinavlarla hala devam etmektedir.

Stalnaker ve Stalnaker (1935), "Chance vs. Selected Distractors in a Vocabulary Test" isimli çalışmalarında, çoktan seçmeli dizayn edilmiş ölçme araçlarında çeldirici kullanımının avantajları üzerinde durmuşlardır. Çalışmada 657 üniversite birinci sınıf öğrencisine bir kelime testi uygulanmıştır. Ölçme aracı, iki seçili ve iki seçilmemiş dört çeldiriciden oluşan beş seçenekli bir ölçektir. Burada seçili çeldirici, kelimelerin eş anlamlıları, zit anlamlıları ya da anlamca birbirine çok yakın kelimelerden oluşur. Yapılan analizden elde edilen bilgilere göre, seçili çeldiricilerin kullanımının maddenin ayırıcılığını engellemediği sonucuna ulaşılmıştır ve seçili çeldiricilerin kullanımı tavsiye edilmiştir.

Schmitt ve Dorans (1990), "Differential Item Functioning for Minority Examinees on the SAT" isimli çalışmalarında, standart çeldirici analizi kullanılarak değişen madde fonksiyonu belirleme yöntemi üzerinde durmuştur. Ölçme aracı olarak, Skolastik Yetenek Testi kullanılmıştır ve test, Asya Amerikan, Hispanik ve Siyahilere uygulanmıştır. Çalışmada, madde yanlılığının belirlenmesinde çeldiricilerin önemi vurgulanmışır.

Wang (1998), "Rasch Analysis of Distractors in Multiple-Choice Items" isimli çalışmasında, her bir çeldirici için farklı güçlük düzeyleri belirleyen ve güçlük düzeylerini çeldiriciler ile ilişkilendiren aynı zamanda model veri uyumunun yüksek olduğu yeni bir çeldirici modeli önermiştir.
Alagumalai ve Keeves (1999), "Distractors--Can They Be Biased too?" isimli çalışmalarında, çeldiricilerin performanslarını karşılaştırmak için, değişen çeldirici fonksiyonunun incelenmesi gerektiğini öne sürmüşlerdir. Çalışmaya göre, madde ve test düzeyinde yanlılığa bakılmadan önce çeldiriciler için yanlılık araştırmaları yapılmalıdır. Değişen çeldirici fonksiyonuna bakıldığında farklı alt grupların, mevcut özelliklerine göre farklı düzeylerde çeldirici seçenekleri tercih ettikleri görülmüştür.

Hambleton ve Jirka (2006), “Anchor-Based Methods for Judgmentally Estimating Item Statistics" isimli çalışmasında çeldiricilerin, çoktan seçmeli bir maddeyi çözmek için gereken içeriğin önemli bir bölümünü oluşturduğunu ve bu bağlamda, doğru cevabı seçmek için cevaplayıcıların, seçenekler arasında bir ayrım yapmaları gerekmesi nedeniyle doğru ve yanlış seçenekler arasında karmaşık bir ilişki olduğunu belirtmişlerdir.

Gajjar v.d. (2014) "Item and Test Analysis to Identify Quality Multiple Choice Questions (MCQs) from an Assessment of Medical Students of Ahmedabad, Gujarat" isimli çalışmalarında, Ahmedabad Tıp Fakültesinde yapılmış bir sınavdaki, madde güçlük indeksi, madde ayırt edicilik indeksi ve çeldirici etkinliğine bağlı işlerliği araştırmışlardır. Elde edilen bu indekslere göre geçerli bir madde havuzu oluşturulabilmekte ya da bu indeks değerlerine göre gerekli olduğu düşünülen maddeler üzerinde düzenlemeler yapılabilmektedir. $\mathrm{Bu}$ yönüyle çalışmada, test geliştirme sürecinde çeldirici analizinin önemi vurgulanmaktadır.

Wind v.d. (2019) "Exploring Student Understanding of the Engineering Design Process Using Distractor Analysis" isimli çalışmalarında, Rasch ölçümüne dayalı çeldirici analizi yapmıştırlar. 128 yedinci sınıf öğrencisinin 20 çoktan seçmeli maddeye verdiği tepkiler analiz edilmiş ve elde edilen sonuçlara göre, farklı başarı seviyelerine sahip öğrencilerin çeşitli cevap seçeneklerini seçmesinin olasılıklarının değiştiğ $i$ sonucuna ulaşmıştırlar.

$\mathrm{Bu}$ çalışmada, dersin uzmanları tarafindan geliştirilen ve güvenilirlik çalışması yapılmış olan İstatistiğe Giriş Okuryazarlık Testi bünyesindeki maddelere ilişkin çeldirici analizi yapılmıştır. Burada temel amaç, ölçek içerisinde çeldiricilerin davranışlarını gözlemlemek ve yorumlamaktır. Çeldirici analizi, madde güçlük indeksi ve madde ayırt edicilik indeksi ile birlikte madde analizinin 
önemli bir parçasıdır. Bu anlamda çalışmada, çeldiricilerin işlerliği analiz edilirken aynı zamanda çeldiricilerin madde istatistikleri ile ilişskilerinin incelenmesi de amaçlanmıştır.

\section{1. Çoktan Seçmeli Testler}

Ölçek içindeki mevcut maddelerin cevaplarının, belirli sayıda olası cevap seçeneği arasından birinin seçilmesiyle verildiği ölçme araçlarına çoktan seçmeli test denir. $\mathrm{Bu}$ tip testlerde maddeler, madde kökü ve seçenekler olmak üzere

\section{Herhangi bir veri kümesindeki elemanların ortalamadan sapmalarının karelerinin toplamının veri sayısına bölümü aşağıdaki kavramlardan hangisi ile ifade edilebilir?}

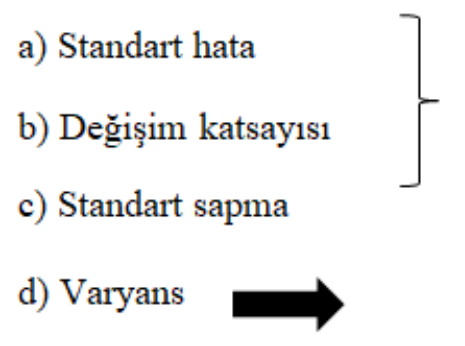

\section{Doğru Yanıt}

Çeldiriciler<smiles>C1CCC1</smiles>

iki başlık altında incelenir. Seçenekler ise kendi aralarında doğru yanıt ve çeldiriciler olarak ikiye ayrılır. İlgili maddenin doğru yanıtı dışındaki tüm seçenekler çeldiriciler olarak tanımlanır (Şencan, 2005; Güler, 2008; Tomak, 2013).

Çoktan seçmeli testlerin konuyla ilgili yeterli uzmanlığa sahip kişilerce hazırlanması gerekmektedir. Aksi halde, ölçme aracındaki maddeler amaca uygunluklarından sapacaktır ve elde edilen ölçme sonuçları hassaslık ve objektiflikten uzak olacaktır.

\section{Madde Kökü}

\section{Seçenekler}

ile ilgili bilgiler bulunmamalıdır. Her bir test maddesi birbirinden bağımsı şekilde düzenlenmelidir. Maddelerde yer alan seçenek sayıları eşit olmalıdır.

\section{2. Çeldirici Analizi}

Çeldirici, çoktan seçmeli bir test maddesindeki doğru cevap seçeneği dışındaki seçeneklerdir. Türk Dil Kurumu'na göre çeldirici, 'Test sınavında, sorunun cevapları arasında doğruya en yakın görünen ancak, yanlış olan şık.' olarak tanımlanmıştır. Çeldiricilerin hazırlanma sürecinde amaç, cevaplayıcının test maddesinin doğru yanıtını bilip bilmediğini ölçmektir.

Çeldirici geliştirme, test geliştirme sürecinin en önemli ve en zor bileşenlerinden biridir. Bunun sebebi de çeldirici geliştirilirken bünyesinde birçok özelliğin barınmasının bekleniyor olmasıdır. Çeldiricilerin sağlaması gereken özelliklerden bazıları; doğru cevapla ilgili hiçbir bilgi taşımamaları, anlam karmaşasından uzak olmaları, okunduğunda net bir şekilde tek bir anlamı vermeleri gibi sıralanabilmektedir.

Çeldirici analizi, madde güçlüğü ve ayırt ediciliğe benzeyen teknikleri kullanarak yapılan madde 
analizinin bir çeşididir. Çeldirici analizi, maddenin iyi yapılandırılıp yapılandırılmadığını ya da amacını yerine getirip getirmediğini gösteren bir araçtır. Çeldiricilerin kalitesi, cevaplayıcının test maddesi üzerindeki performansinı etkiler.

Çeldirici analizi, güçlük ve ayırt edicilik indekslerinden sonra madde analizinin önemli bir bileşenidir. Thissen v.d. (1989), "Multiple Choice Models: The Distractors are Also Part of the Item" isimli çalışmalarında çeldiricilerin ve doğru cevabın, maddeyi oluşturan yapitaşlarından olduğunu dolayısıyla, madde analizinin de bir parçası olduğunu belirtmişlerdir. Çeldiriciler, maddenin kalitesinin belirlenmesinde önemli bir rol üstlenir. Araştırıcılar, cevaplayıcılardan hiçbir çeldiriciye düşmeden doğru seçeneği işaretlemelerini beklemektelerdir. Çeldiricilerin etkinliği, cevaplayıcının maddeye vereceği tepkiyi doğrudan etkilemektedir.

Bir seçeneğin en iyi çeldirici olabilmesi için ilgili çeldiriciyi alt gruptan seçenlerin sayısı ile üst gruptan seçenlerin sayısının farkının diğer seçeneklerle kıyaslandığında maksimum olması gerekmektedir. Bir seçeneğin en güçlü çeldirici olması için ise, her iki gruptan da en çok kişiyi kendisine çeken çeldirici olması gerekmektedir. Çeldirici seçeneklerin etkili şekilde çalıştı̆̆ını söyleyebilmek için her birinin yeterli miktarda cevaplayıcı tarafından seçilmesi gerekir.

Çeldiricilerin etkinliğini belirlemek için her bir çeldiricinin seçilme sayısı not edilir. Haladyna ve Downing (1993)'e göre, cevaplayıcıların \%5'inden daha azının seçtiği bir çeldirici etkili olmayan bir çeldirici olarak kabul edilir. Ancak her zaman bu yorumu yapmak araştırıcıyı yanlışa da götürebilir. Örneğin; yapılan madde analizi sonucunda bir madde çok kolay şeklinde yorumlanmışsa bu durumda cevaplayıcıların çeldiricilere düşme oranının düşük olması beklenen bir durumdur. Böyle bir madde için düşük oranlı çeldiricilerin etkin çeldiriciler olmadığını söylemek doğru olmayabilir.

Çeldirici analizinin ana amacı, ölçme aracı içerisindeki maddelerden gözden geçirilmesi ve yenilenmesi gereken maddeleri belirlemek, etkin olmayan çeldiricileri ortadan kaldırmak ve çoktan seçmeli maddelerin ayırıcılık gücünü artırmaktır (Haladyna, 2016).

Çeldirici analizi, toplam test puanı ile cevaplayıcının seçtiği çeldirici arasında bir ilişki olduğunu söylemektedir. Cevaplayıcının madde üzerindeki performansı çeldiricilerin hazırlanışına bağlı olarak farklılık gösterebilmektedir. Ölçme aracı kapsamında bulunan maddeler için yapılan çeldirici analizleri sayesinde maddelerdeki bazı sebeplerden kaynaklı hataları belirlemek daha kolay bir hal almaktadır (Hingorjo ve Jaleel, 2012).

\section{3. Çeldiricilerin Madde İstatistikleri ile İlișkisi}

Bir çeldiricinin etkin olduğunu söyleyebilmek için belirli bir işaretlenme sayısının yakalaması gerekir. Bu noktada akla bu değerin ne olduğu sorusu gelmektedir. Sorunun cevabını madde güçlük indeksi ile vermek mümkündür. Örneğin; dört seçenekli çoktan seçmeli bir test maddesi için güçlük indeksinin 0.40 olduğu kabul edilsin. $\mathrm{Bu}$ durum 100 kişinin aldığ bir testte 40 kişinin ilgili maddeyi doğru cevaplaması anlamına gelmektedir. Geri kalan 60 kişinin kalan üç çeldiriciyi eşit olarak seçmesi beklenen bir durumdur. Beklenen durumun gerçekleşmesi halinde ise her bir çeldiriciye 20 kişi düşmektedir.

Her bir maddenin güçlük indeksi olduğu gibi, ilgili maddenin bünyesinde bulunan her bir çeldiricinin de güçlük indeksi mevcuttur. Beklenen durum gerçekleştiğinde, her bir çeldiricinin güçlük indeksi 20/100'den 0.20 bulunmaktadır. Çeldiricilerin güçlük indeksi ile ilişkisi bu şekilde açıklanabilir. Madde güçlük indeksi ve çeldirici güçlük indeksi benzer şekilde hesaplanır ancak ayrıldıkları nokta, madde güçlük indeksi değeri, ölçme aracı içerisindeki diğer maddelerden bağımsız bir değerken, çeldirici güçlük indeksi ilgili maddenin diğer seçeneklerinin aldığı güçlük indeksi değerine bağlı olarak değişmektedir.

Güçlük indeksinde olduğu gibi ayırt edicilik indeksinde de çeldirici analizi ile benzer noktalar mevcuttur. Çeldiricin nasıl çalıştığını analiz etmek ve test maddesinin etkinliğini belirlemek için her bir çeldiricinin kendi ayırt edicilik indeksi vardır. Tüm bu benzerliklerin yanı sıra, alt ve üst gruplar yöntemi ile kestirilen ayırt edicilik indeksinin elde edilmiş sonuçları çeldiriciler için farkl11ık göstermektedir. Madde ayırt ediciliği ile çeldirici ayırt ediciliği arasındaki fark, madde ayırt ediciliğinde beklenenin aksine iyi bir çeldirici için ayırt ediciliğin negatif çıkmasıdır. Bunun sebebi ise ayırt ediciliğin formülünden kolayca görülebilmektedir.

$$
a_{c ̧ i}=\frac{\text { üst gruptan seçenler }- \text { alt gruptan seçenler }}{\text { kitlenin } \% 33.3 \text { ’̈ }}
$$


İyi bir çeldiriciyi alt gruptan seçenlerin sayısının daha fazla olması beklendiğinden çeldirici ayırt ediciliğinin negatif çıkması beklenmektedir.

Çeldirici analizinden bulunan sonuçların yanı sıra her bir madde için grafikler de elde edilmektedir. Madde grafikleri ile araştırıcılar etkin bir şekilde çalışmayan çeldiricileri daha kolay tespit etmekte ve gerekirse değiştirebilmektedir. Attali ve Fraenkel (2000)'e göre, çeldiricileri değerlendirmenin bir diğer yolu, nokta-biserial korelasyondur. Bir çeldiricinin nokta-biserial korelasyonu hesaplanırken araştırmacıların, çeldiriciyi seçen cevaplayıcıları karşılaştırması gerekir (Gierl v.d., 2017).

\section{Yöntem}

$\mathrm{Bu}$ çalışmada, Karadeniz Teknik Üniversitesi İktisadi ve İdari Bilimler Fakültesi Ekonometri Bölümü öğrencilerine İstatistik Okuryazarlık Testi uygulanmıştır. Testi uygulamadan önce Ekonometri bölümünde İstatistiğe Giriş ya da İstatistik I dersini almış öğrenciler tespit edilmiştir. Geliştirilen ölçme aracı belirlenen bu öğrencilere uygulanmıştır. Test, önceden belirlenmiş 139 öğrenciye uygulanmıştır. 139 öğrenci ilgili dersleri alan tüm öğrencilerin sayısıdır. 139 öğrencinin 88'i kadın 51'i erkektir. İstatistik Okuryazarlık Testi oluşturulurken maddeler İstatistik dersinin kazanımları göz önüne alınarak hazırlanmıştır. Tüm maddeler dersin uzmanları tarafından geliştirilmiştir.

Geliştirilen ölçme aracı 25 maddeden oluşmaktadır. Her bir madde dört seçenekli olarak tasarlanmıştır. Ölçme aracındaki tüm maddelerin seçeneklerinden biri doğru yanıt geri kalan üçü de çeldirici olarak dizayn edilmiştir. Böylelikle çoktan seçmeli bir ölçme aracı oluşturulmuştur. Analizlere başlamadan önce madde tepki vektörünün oluşturulması gerekmektedir. Madde tepki vektörü cevaplayıcıların maddelere verdikleri yanitlar baz alınarak oluşturulur. $\mathrm{Bu}$ çalışmada, yanlış cevaplar için 0 , doğru cevaplar için 1 değeri atanmış ve madde tepki vektörü 0 ve 1'lerden meydana gelen ikili bir şekilde oluşturulmuştur.

İstatistiğe Giriş Okuryazarlık Testi çeldirici analizi R yazılımında ShinyItemAnalysis ve CTT paketleri kullanılarak yapılmıştır. Çeldirici analizi ile tüm seçenekler için tercih edilme sayıları, alt ve üst gruplardaki cevaplayıcılar tarafindan seçeneklerin tercih edilme oranları, seçeneklerin ayırt edicilikleri ve cevaplayıcının toplam test puanı ile seçtiği seçenek arasındaki ilişkiyi gösteren nokta-biserial korelasyon katsayıları elde edilmiştir. Elde edilen bu bilgiler ışı̆̆ında ilgili maddelerin çeldiricilerinin kalitesi ile ilgili yorumlar yapılmıştır. Ayrıca, analiz kapsamında çeldirici grafikleri ile her bir seçeneğin davranışını da görmek mümkündür. Grafikler yardımı ile alt ve üst gruplardaki bireylerin seçenekleri seçme eğilimlerine göre etkin çalışan çeldiricilerin ve etkin çalışmayan çeldiricilerin davranışları görülmektedir. $\mathrm{Bu}$ çalışmada, ölçme aracı kapsamında bazı maddeler seçilerek etkin çalışan çeldiricilere ve etkin çalışmayan çeldiricilere örnekler verilmiştir.

Madde analizine başlamadan önce veri setinde tek değişkenli ve çok değişkenli aykırı değerlerin olup olmadığı incelenmiştir. Tek değişkenli aykırı değer analizi için z puanları hesaplanmış ve \pm 3 değerinin aşılıp aşılmadığına bakılmıştır. Analiz sonucu elde edilen $\mathrm{z}$ değerlerinden \pm 3 sinırını aşan değerin olmadığı tespit edilmiştir. Buradan hareketle veri seti içerisinde tek değişkenli aykırı değer olmadığı saptanmıştır. Çok değişkenli aykırı değerlerin tespiti için Mahalanobis uzaklıkları hesaplanmıştır. Hesaplamadan elde edilen Mahalanobis uzaklık değerleri incelenmiş ve veri setinde çok değişkenli aykırı değerin olmadığı saptanmıştır (Uyar ve Doğan, 2014).

Tablo 3.'de her bir madde için Corrected ItemTotal Correlation ve Cronbach $\alpha$ if item deleted değerleri verilmiştir. Corrected Item-Total Correlation değerleri, ilgili madde ile ölçekteki diğer maddelerin oluşturduğu bütün arasındaki korelasyonları ifade eder. Bu değerlerin düşük çıkması, ilgili maddenin ölçeğe katkısının az olması demektir. Cok küçük ve negatif Corrected Item-Total Correlation değerine sahip maddeler ölçekten çıkarılmalıdır. Böylelikle, ölçeğin güvenilirliğinin arttırılması amaçlanır. Cristobal vd. (2007)'a göre, Corrected Item-Total Correlation değeri 0.3 'ün altında olan maddeler ölçekten çıkarılmalıdır. Tablo 3.'de verilmiş Corrected Item- Total Correlation değerlerinin hepsi 0.3 değerinin üzerindedir. Buradan, hiçbir maddenin ölçekten atılmayacağı sonucuna ulaşılır. Bununla birlikte, Tablo 3.'de Cronbach $\alpha$ if item deleted değerleri de gözlemlenmektedir. Bu değerler ile, ilgili maddenin ölçekten çıkarılması durumunda, geride kalan maddelerden hesaplanan ölçek güvenilirliğine ulaşılır. Tablo 3.'den görüldüğ̈̈ gibi her bir maddenin güvenilirliği 0.91 civarında hesaplanmıştır.

Bir ölçeğin iç tutarlllı̆̆ının belirlenmesi için o ölçekten elde edilen toplam puanlar ve madde puanları alınır. Toplam puanların maddenin 
geçerliği için ölçüt alınmasının temelinde, denenen maddelerin testle ölçülmek istenen özelliği ölçüp ölçmediğine bakmaktır (Turgut, 1979). İç tutarlılığın ölçülmesi için \%27'lik alt ve üst grupların ortalamalarının madde bazında karşılaştırılması gerekmektedir (Flanagan, 1952). Analiz sonucu maddelerin bireyleri ölçülen davranış bakımından ne derece ayırt ettiğini gösterir. Madde ayırt ediciliği açısından bu gruplar arasında istatistiksel olarak anlamlı bir farklı1ık çıkması beklenir. İç tutarlılık ölçümü için Bağımsız Örnek T Testi uygulanır ve alt ve üst grubun madde puanları arasinda fark yoktur biçiminde oluşturulan yokluk hipotezi test edilir.

$H_{0}$ : Alt ve Üst $\% 27^{\prime}$ lik madde puanları arasında fark yoktur.

$H_{1}$ : Alt ve Üst \%27'lik madde puanları arasında fark vardır.

Tablo 2. Maddeler için Corrected Item- Total Correlation ve Cronbach $\alpha$ if item deleted değerleri

\begin{tabular}{|c|c|c|}
\hline Maddeler & Corrected Item- Total Correlation & Cronbach $\boldsymbol{\alpha}$ if Item deleted \\
\hline S1 & 0.373 & 0.919 \\
\hline S2 & 0.316 & 0.918 \\
\hline S3 & 0.588 & 0.913 \\
\hline S4 & 0.588 & 0.913 \\
\hline S5 & 0.588 & 0.913 \\
\hline S6 & 0.586 & 0.913 \\
\hline S7 & 0.429 & 0.916 \\
\hline S8 & 0.602 & 0.913 \\
\hline S9 & 0.620 & 0.913 \\
\hline S10 & 0.428 & 0.916 \\
\hline S11 & 0.620 & 0.913 \\
\hline S12 & 0.683 & 0.911 \\
\hline S13 & 0.714 & 0.911 \\
\hline S14 & 0.621 & 0.913 \\
\hline S15 & 0.678 & 0.911 \\
\hline S16 & 0.641 & 0.912 \\
\hline S17 & 0.545 & 0.914 \\
\hline S18 & 0.641 & 0.912 \\
\hline S19 & 0.624 & 0.913 \\
\hline S20 & 0.641 & 0.912 \\
\hline S21 & 0.424 & 0.916 \\
\hline S22 & 0.369 & 0.917 \\
\hline S23 & 0.335 & 0.918 \\
\hline S24 & 0.359 & 0.917 \\
\hline S25 & 0.347 & 0.918 \\
\hline Tüm test & & 0.917 \\
\hline & & \\
\hline & & \\
\hline
\end{tabular}

Tablo 4.'de \%27'lik alt ve üst gruplar için bağımsız örnek $t$ testi sonuçları görülmektedir. $p$ değerlerine bakıldığında hepsinin anlamlılık düzeyi 0.05 'den küçük olması sebebiyle tüm maddeler için yokluk hipotezi reddedilir. Buradan alt ve üst gruplar arasında istatistiksel olarak anlamlı bir farkl1lık olduğu söylenebilmektedir.

Çeldiriciler madde istatistikleri yardımıyla yorumlanabilir. Madde istatistiklerinden yola çıkılarak çeldiriciler için hesaplanan istatistikler, çeldirici analizinin önemli bir parçasıdır. Şekil 1.'de Madde Güçlük ve Madde Ayırt Edicilik indekslerinin hesaplanmasiyla elde edilen Güçlük/Ayırıcılık grafiği görülmektedir. Şekil 1.'de yatay eksende maddeler güçlük indekslerine göre sıralanmıştır. Buradan hareketle İstatistiğe Giriş Okuryazarlık Testi için Madde Güçlük İndeksi en yüksek olan madde 8 numaralı madde iken Ayırt Edicilik İndeksi en yüksek olan madde 13 numaralı maddedir. 
Tablo 3. Alt ve Üst grupların ortalamaları arasındaki farklara ilişkin Bağımsız Örnek T Testi

\begin{tabular}{|c|c|c|c|c|}
\hline \multicolumn{2}{|c|}{ Maddeler } & \multirow{2}{*}{$\begin{array}{l}\mathbf{t} \text { istatistiği } \\
5.245 \\
5.282\end{array}$} & \multirow{2}{*}{$\begin{array}{l}\text { Serbestlik derecesi } \\
75 \\
59.998\end{array}$} & \multirow{2}{*}{$\begin{array}{l}\text { p değeri } \\
0.000 \\
0.000\end{array}$} \\
\hline S1 & $\begin{array}{l}\text { Varyanslar eşit } \\
\text { Varyanslar esit değil }\end{array}$ & & & \\
\hline S2 & $\begin{array}{l}\text { Varyanslar eşit } \\
\text { Varyanslar eşit değil }\end{array}$ & $\begin{array}{l}6.728 \\
6.670\end{array}$ & $\begin{array}{l}75 \\
51.520\end{array}$ & $\begin{array}{l}0.000 \\
0.000\end{array}$ \\
\hline S3 & $\begin{array}{l}\text { Varyanslar eşit } \\
\text { Varyanslar eşit değil }\end{array}$ & $\begin{array}{l}10.313 \\
10.178 \\
\end{array}$ & $\begin{array}{l}75 \\
37 \\
\end{array}$ & $\begin{array}{l}0.000 \\
0.000 \\
\end{array}$ \\
\hline S4 & $\begin{array}{l}\text { Varyanslar eşit } \\
\text { Varyanslar eşit değil }\end{array}$ & $\begin{array}{l}10.313 \\
10.178 \\
\end{array}$ & $\begin{array}{l}75 \\
37 \\
\end{array}$ & $\begin{array}{l}0.000 \\
0.000 \\
\end{array}$ \\
\hline S5 & $\begin{array}{l}\text { Varyanslar eşit } \\
\text { Varyanslar eşit değil }\end{array}$ & $\begin{array}{l}10.313 \\
10.178 \\
\end{array}$ & $\begin{array}{l}75 \\
37 \\
\end{array}$ & $\begin{array}{l}0.000 \\
0.000\end{array}$ \\
\hline S6 & $\begin{array}{l}\text { Varyanslar eşit } \\
\text { Varyanslar eşit değil }\end{array}$ & $\begin{array}{l}9.397 \\
9.492\end{array}$ & $\begin{array}{l}75 \\
48.269\end{array}$ & $\begin{array}{l}0.000 \\
0.000\end{array}$ \\
\hline S7 & $\begin{array}{l}\text { Varyanslar eşit } \\
\text { Varyanslar eşit değil }\end{array}$ & $\begin{array}{l}6.850 \\
6.761 \\
\end{array}$ & $\begin{array}{l}75 \\
37 \\
\end{array}$ & $\begin{array}{l}0.000 \\
0.000\end{array}$ \\
\hline S8 & $\begin{array}{l}\text { Varyanslar eşit } \\
\text { Varyanslar eșit değil }\end{array}$ & $\begin{array}{l}11.287 \\
11.319\end{array}$ & $\begin{array}{l}75 \\
72.502\end{array}$ & $\begin{array}{l}0.000 \\
0.000\end{array}$ \\
\hline S9 & $\begin{array}{l}\text { Varyanslar eşit } \\
\text { Varyanslar eşit değil }\end{array}$ & $\begin{array}{l}11.611 \\
11.502\end{array}$ & $\begin{array}{l}75 \\
48.706\end{array}$ & $\begin{array}{l}0.000 \\
0.000\end{array}$ \\
\hline S10 & $\begin{array}{l}\text { Varyanslar eşit } \\
\text { Varyanslar eşit değil }\end{array}$ & $\begin{array}{l}6.001 \\
5.949\end{array}$ & $\begin{array}{l}75 \\
50.906\end{array}$ & $\begin{array}{l}0.000 \\
0.000\end{array}$ \\
\hline S11 & $\begin{array}{l}\text { Varyanslar eşit } \\
\text { Varyanslar eşit değil }\end{array}$ & $\begin{array}{l}15.493 \\
15.609\end{array}$ & $\begin{array}{l}75 \\
57.968\end{array}$ & $\begin{array}{l}0.000 \\
0.000\end{array}$ \\
\hline S12 & $\begin{array}{l}\text { Varyanslar eşit } \\
\text { Varyanslar eşit değil }\end{array}$ & $\begin{array}{l}17.996 \\
18.235 \\
\end{array}$ & $\begin{array}{l}75 \\
38 \\
\end{array}$ & $\begin{array}{l}0.000 \\
0.000 \\
\end{array}$ \\
\hline S13 & $\begin{array}{l}\text { Varyanslar eşit } \\
\text { Varyanslar eşit değil }\end{array}$ & $\begin{array}{l}20.683 \\
20.767 \\
\end{array}$ & $\begin{array}{l}75 \\
69.379 \\
\end{array}$ & $\begin{array}{l}0.000 \\
0.000 \\
\end{array}$ \\
\hline S14 & $\begin{array}{l}\text { Varyanslar eşit } \\
\text { Varyanslar eşit değil }\end{array}$ & $\begin{array}{l}15.834 \\
15.627\end{array}$ & $\begin{array}{l}75 \\
37 \\
\end{array}$ & $\begin{array}{l}0.000 \\
0.000\end{array}$ \\
\hline S15 & $\begin{array}{l}\text { Varyanslar eşit } \\
\text { Varyanslar eşit değil }\end{array}$ & $\begin{array}{l}15.834 \\
15.627\end{array}$ & $\begin{array}{l}75 \\
37 \\
\end{array}$ & $\begin{array}{l}0.000 \\
0.000\end{array}$ \\
\hline S16 & $\begin{array}{l}\text { Varyanslar eşit } \\
\text { Varyanslar eşit değil }\end{array}$ & $\begin{array}{l}13.887 \\
13.770\end{array}$ & $\begin{array}{l}75 \\
52.130\end{array}$ & $\begin{array}{l}0.000 \\
0.000\end{array}$ \\
\hline S17 & $\begin{array}{l}\text { Varyanslar eşit } \\
\text { Varyanslar eşit değil }\end{array}$ & $\begin{array}{l}10.531 \\
10.460\end{array}$ & $\begin{array}{l}75 \\
58.357\end{array}$ & $\begin{array}{l}0.000 \\
0.000\end{array}$ \\
\hline S18 & $\begin{array}{l}\text { Varyanslar eşit } \\
\text { Varyanslar eşit değil }\end{array}$ & $\begin{array}{l}13.887 \\
13.770\end{array}$ & $\begin{array}{l}75 \\
52.130\end{array}$ & $\begin{array}{l}0.000 \\
0.000\end{array}$ \\
\hline S19 & $\begin{array}{l}\text { Varyanslar eşit } \\
\text { Varyanslar eşit değil }\end{array}$ & $\begin{array}{l}12.429 \\
12.363\end{array}$ & $\begin{array}{l}75 \\
63.424\end{array}$ & $\begin{array}{l}0.000 \\
0.000\end{array}$ \\
\hline S20 & $\begin{array}{l}\text { Varyanslar eşit } \\
\text { Varyanslar eşit değil }\end{array}$ & $\begin{array}{l}13.887 \\
13.770 \\
\end{array}$ & $\begin{array}{l}75 \\
52.130 \\
\end{array}$ & $\begin{array}{l}0.000 \\
0.000 \\
\end{array}$ \\
\hline S21 & $\begin{array}{l}\text { Varyanslar eşit } \\
\text { Varyanslar eşit değil }\end{array}$ & $\begin{array}{l}5.633 \\
5.707 \\
\end{array}$ & $\begin{array}{l}75 \\
38 \\
\end{array}$ & $\begin{array}{l}0.000 \\
0.000 \\
\end{array}$ \\
\hline S22 & $\begin{array}{l}\text { Varyanslar eşit } \\
\text { Varyanslar eşit değil }\end{array}$ & $\begin{array}{l}3.600 \\
3.618 \\
\end{array}$ & $\begin{array}{l}75 \\
66.919 \\
\end{array}$ & $\begin{array}{l}0.001 \\
0.001 \\
\end{array}$ \\
\hline S23 & $\begin{array}{l}\text { Varyanslar eşit } \\
\text { Varyanslar eşit değil }\end{array}$ & $\begin{array}{l}3.114 \\
3.122 \\
\end{array}$ & $\begin{array}{l}75 \\
72.837 \\
\end{array}$ & $\begin{array}{l}0.003 \\
0.003 \\
\end{array}$ \\
\hline S24 & $\begin{array}{l}\text { Varyanslar eşit } \\
\text { Varyanslar eşit değil }\end{array}$ & $\begin{array}{l}3.346 \\
3.363\end{array}$ & $\begin{array}{l}75 \\
67.014\end{array}$ & $\begin{array}{l}0.001 \\
0.001\end{array}$ \\
\hline S25 & $\begin{array}{l}\text { Varyanslar eşit } \\
\text { Varyanslar eşit değil }\end{array}$ & $\begin{array}{l}3.690 \\
3.702\end{array}$ & $\begin{array}{l}75 \\
71.673\end{array}$ & $\begin{array}{l}0.000 \\
0.000\end{array}$ \\
\hline
\end{tabular}

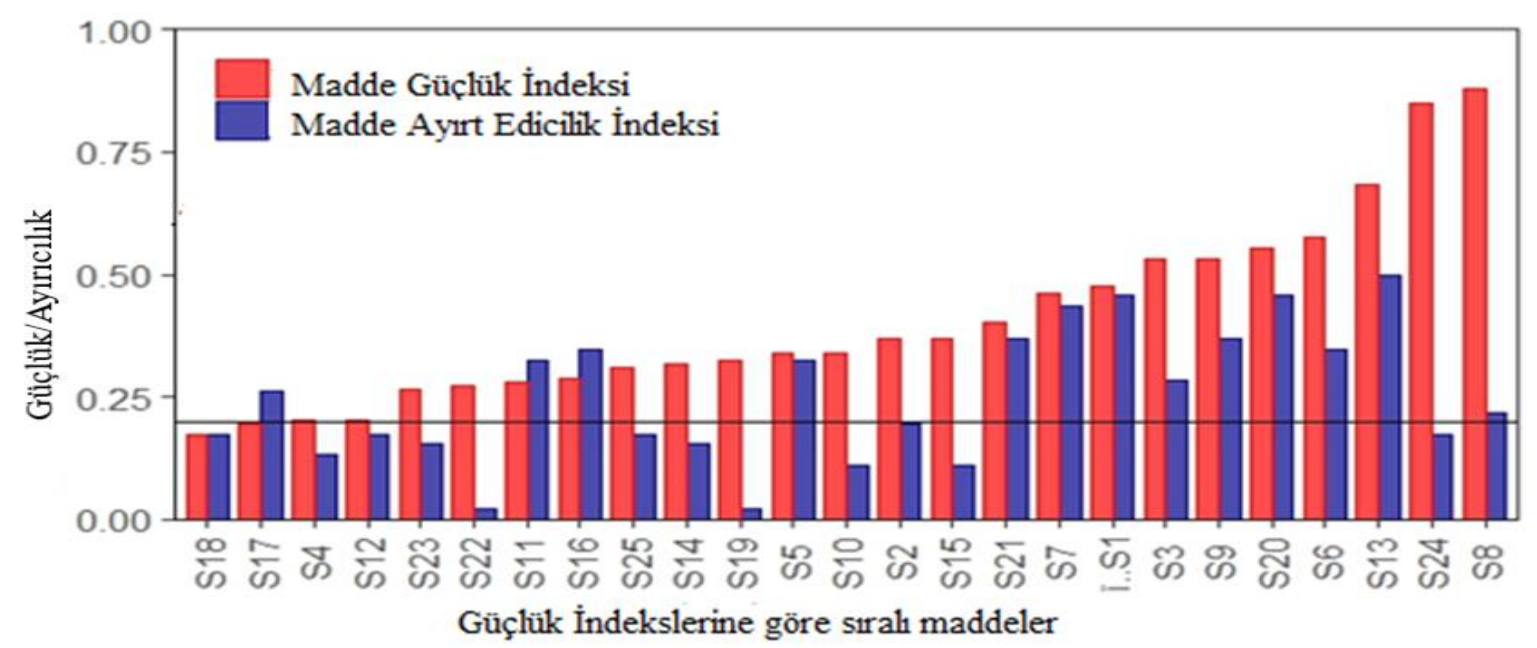

Şekil 1. Güçlük/Ayırt Edicilik grafiği 


\section{Bulgular}

Çalı̧̧ma, İstatistiğe Giriş düzeyinde ders almış Ekonometri Bölümü öğrencilerinin, İstatistik okuryazarlıklarını ölçen bir ölçme aracındaki maddelerin, çeldirici analizlerinin yapılması ve elde edilen sonuçlardan hareketle, maddelerin test içindeki performansları ve maddelerin bünyesindeki seçeneklerin performansı hakkında yorumlar yapmaya dayanmaktadır.
Tablo 5.'de İstatistiğe Giriş Okuryazarlık Testi için betimleyici bilgiler görülmektedir. Ölçeği alan 139 öğrenciden 88'i kadın 51'i erkektir. Testin ortalama ham puanı 10.1798 'dir. Alınan en yüksek ham puan 16 iken en düşük puan 4' dür. Puanlama yapılırken doğru cevaplara 1 , yanlış cevaplara 0 puan atanmıştır.

Tablo 4. Tanımlayıcı İstatistikler

\begin{tabular}{|c|c|c|c|c|c|c|}
\hline Kadın & Erkek & Ortalama puan & Std sapma & Max puan & Min puan & Değişim aralığı \\
\hline 88 & 51 & 10.1798 & 2.6925 & 16 & 4 & 12 \\
\hline
\end{tabular}

Ölçme aracından seçilmiş bazı maddeler için çeldirici analizinin sonuçları tablolar ve grafikler ile gösterilmiştir. Tablo 6.' da 1 numaralı madde için bilgiler yer almaktadır. Tablo 6.'dan görüldügü üzere 1 . madde için doğru yanıt $C$ seçeneğidir ve 67 kiși tarafından tercih edilmiștir. Seçeneklerin ayırt edicilikleri ve nokta-biserial korelasyon katsayıları ile alt ve üst gruplardaki cevaplayıcıların seçilme oranlarını tablodan görmek mümkündür.

Tablo 5.Madde 1 için seçenek frekans tablosu

\begin{tabular}{|c|c|c|c|c|c|c|}
\hline S1. Cevaplar & Kişi sayısı & Seçenlerin oranı & pBis & Ayırıcılık & Alt grup & Üst grup \\
\hline A & 6 & 0.043478261 & -0.25534 & -0.6666667 & 0.6666667 & 0 \\
\hline B & 52 & 0.376811594 & -0.43484 & -0.3076923 & 0.4230769 & 0.1153846 \\
\hline C & 67 & 0.485507246 & 0.219811 & 0.19402985 & 0.1791045 & 0.3731343 \\
\hline D & 13 & 0.094202899 & -0.17308 & -0.1538462 & 0.2307692 & 0.0769231 \\
\hline
\end{tabular}

Şekil 2.'de madde 1'e ait seçeneklerin alt ve üst gruplardaki davranışları görülmektedir. Yatay eksende alt ve üst gruplar dikey eksende de bu gruplardaki mevcut seçenekleri seçme olasılıkları verilmiştir. Buradan madde 1'e ait doğru seçenek ve çeldiricilerin davranışlarının alt ve üst gruplardaki değişimini görmek mümkündür.

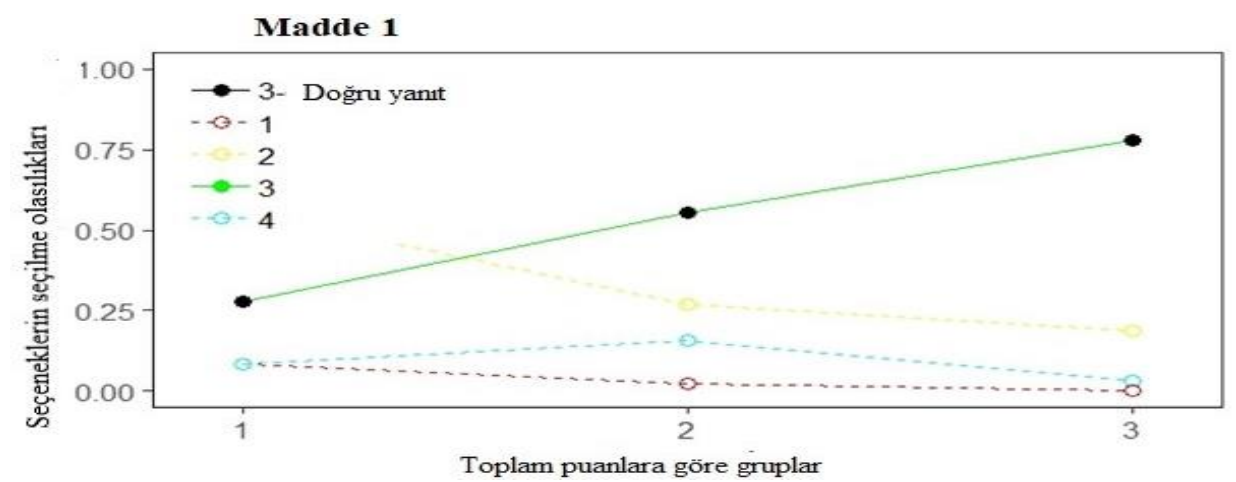

Şekil 2. Madde 1 için çeldirici grafiği 
Tablo 7.'de madde 5'e ait çeldirici frekans tablosunu görmek mümkündür. Tablodan 5. madde için doğru seçeneğin $\mathrm{C}$ seçeneği olduğu görülmektedir. Doğru yanıtı 49 kişi seçmiştir.
Çeldiriciler için frekanslar, korelasyon katsayıları ve alt ve üst gruptaki yüzdeler Tablo 7.'den kolayca görülebilmektedir.

Tablo 6.Madde 5 için seçenek frekans tablosu

\begin{tabular}{|c|c|c|c|c|c|c|}
\hline S5. Cevaplar & Kişi sayısı & Seçenlerin oranı & pBis & Ayırıcılık & Alt grup & Üst grup \\
\hline A & 11 & 0.07971 & -0.21474 & -0.36364 & 0.363636 & 0 \\
\hline B & 35 & 0.253623 & -0.21978 & -0.14286 & 0.285714 & 0.142857 \\
\hline C & 49 & 0.355072 & 0.146083 & 0.244898 & 0.183673 & 0.428571 \\
\hline D & 43 & 0.311594 & -0.35003 & -0.27907 & 0.418605 & 0.139535 \\
\hline
\end{tabular}

Şekil 3.'de doğru yanıt C seçeneğinin ve geri kalan üç çeldiricinin alt ve üst gruplardaki değişen davranışlarını yani alt ve üst gruptaki bireylerin seçenekleri tercih etmelerine göre değiş̧en olasılıkları görmek mümkündür.

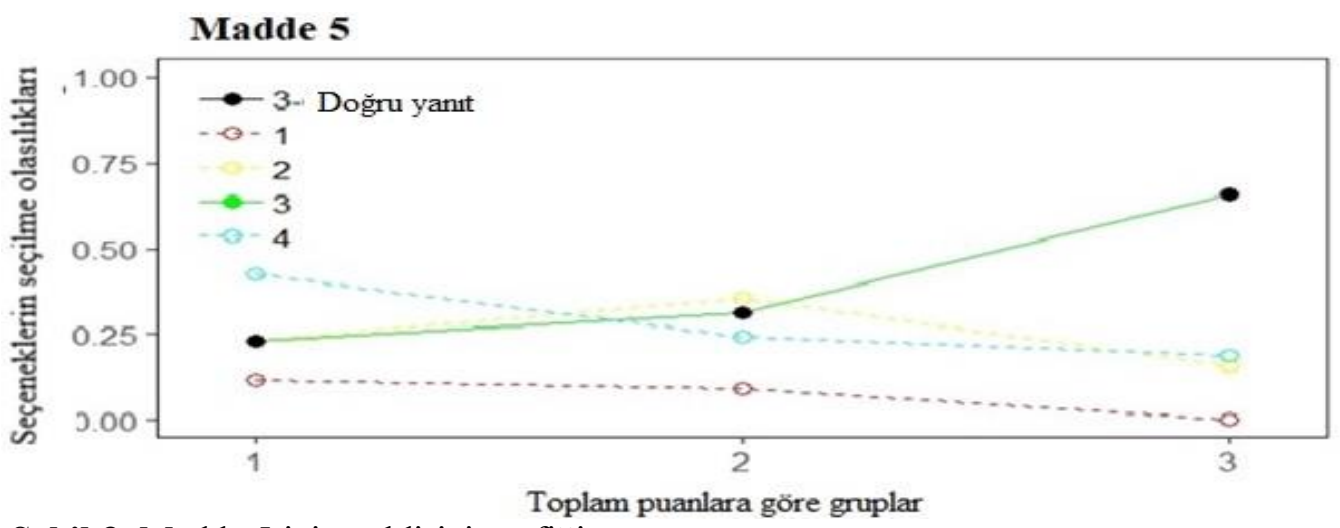

Şekil 3. Madde 5 için çeldirici grafiği

Tablo 8.'de madde 7'ye ait çeldirici frekans tablosunu görmek mümkündür. Tablodan 7 . madde için doğru seçeneğin $B$ seçeneği olduğu görülmektedir. Doğru yanıtı 64 kişi seçmiştir.
Çeldiriciler için frekanslar, korelasyon katsayıları ve alt ve üst gruptaki yüzdeler Tablo 8.'den kolayca görülebilmektedir.

Tablo 7.Madde 7 için seçenek frekans tablosu

\begin{tabular}{|c|c|c|c|c|c|c|}
\hline S7. Cevaplar & Kişi sayısı & Seçenlerin oranı & pBis & Ayırıcılık & Alt grup & Üst grup \\
\hline A & 27 & 0.195652 & -0.27259 & -0.25926 & 0.333333 & 0.074074 \\
\hline B & 64 & 0.463768 & 0.230438 & 0.265625 & 0.140625 & 0.406250 \\
\hline C & 10 & 0.072464 & -0.37022 & -0.80000 & 0.800000 & 0 \\
\hline D & 37 & 0.268116 & -0.31287 & -0.29730 & 0.405405 & 0.108108 \\
\hline
\end{tabular}

Şekil 4.'de doğru yanıt B seçeneğinin ve geri kalan üç çeldiricinin alt ve üst gruplardaki değişen davranışlarını gözlemlemek mümkündür. Buradan hareketle çeldiriciler ile ilgili yorumlar yapılabilmektedir. 


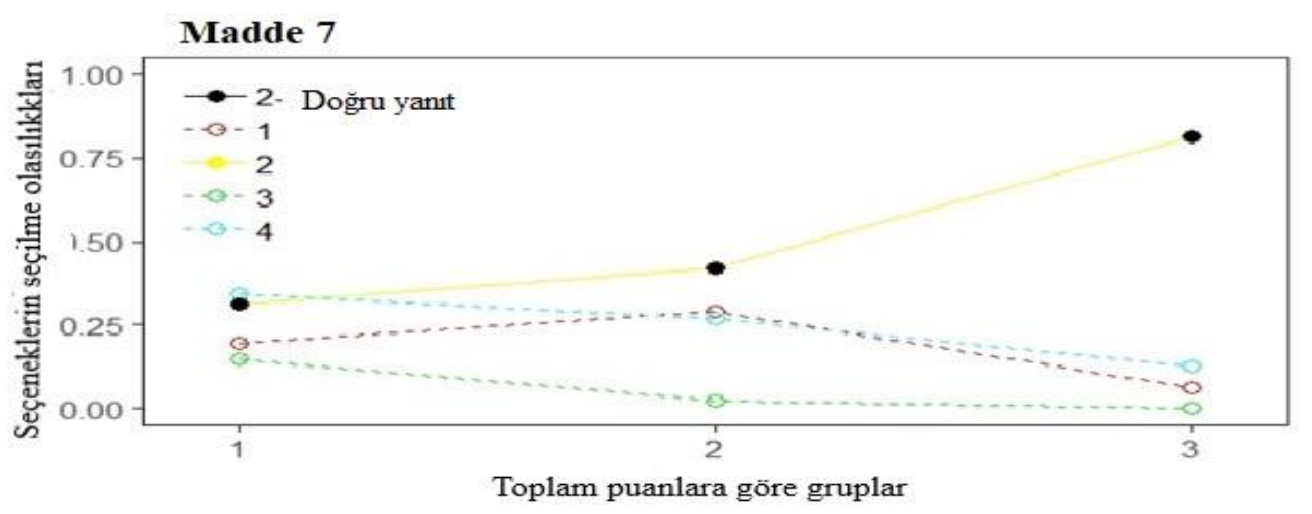

Şekil 4. Madde 7 için çeldirici grafiği

Tablo 9.'da madde 16'ya ait seçenek frekans tablosu görülmektedir. Tabloya göre 16. maddenin doğru yanıtı $\mathrm{D}$ seçeneğidir ve 38 kişi tarafindan tercih edilmiştir. Ancak burada çeldiricilerden B seçeneğinin de 38 kişi tarafından tercih edildiği görülmektedir. $\mathrm{B}$ ve $\mathrm{D}$ seçenekleri için ayırt edicilik ve nokta-biserial korelasyon değerlerine bakıldığında ise beklendiği üzere çeldirici seçenek B için ayırıcılık ve korelasyon değerlerinin negatif olduğu görülür. Doğru yanıt D seçeneğinin ise ayırıcılık ve korelasyon değeri pozitif olan tek seçenek olduğu tablodan görülmektedir.

Tablo 8.Madde 16 için seçenek frekans tablosu

\begin{tabular}{|c|c|c|c|c|c|c|}
\hline S16. Cevaplar & Kişi sayısı & Seçenlerin oranı & pBis & Ayırıcılık & Alt grup & Üst grup \\
\hline A & 31 & 0.224638 & -0.25981 & -0.16129 & 0.354839 & 0.193548 \\
\hline B & 38 & 0.275362 & -0.28095 & -0.18421 & 0.368421 & 0.184211 \\
\hline C & 31 & 0.224638 & -0.25981 & -0.25806 & 0.387097 & 0.129032 \\
\hline D & 38 & 0.275362 & 0.182635 & 0.289474 & 0.105263 & 0.394737 \\
\hline
\end{tabular}

Şekil 5.'de doğru yanıt D seçeneğinin ve geri kalan üç çeldiricinin alt ve üst gruplardaki değişen davranışlarını gözlemlemek mümkündür. $\mathrm{B}$ ve $\mathrm{D}$ seçeneğinin aynı tercih sayısına sahip olduğu Tablo 9.'dan görülmüştür. Şekil 5.'e bakıldığında ise bu durumun alt ve üst gruplarda maddeye verilen tepkilerin farklı olmasından kaynaklandığ söylenebilir. Çeldirici seçenek B seçeneğini alt grupta tercih edenlerin sayısı fazla iken doğru yanıt B seçeneğini tercih edenlerin sayısı üst gruba gidildikçe artış göstermektedir.

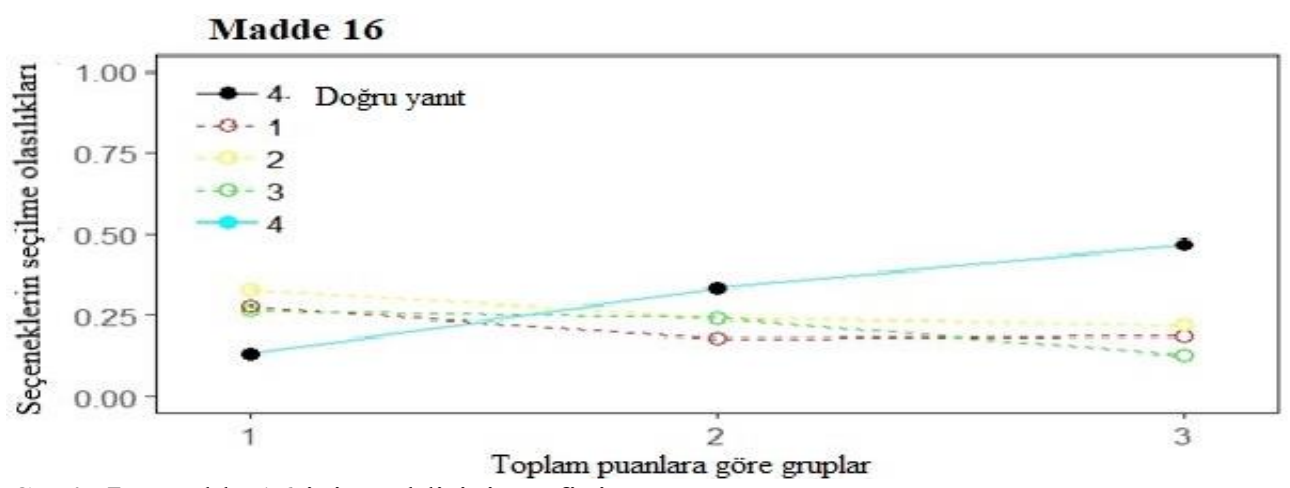

Şekil 5. Madde 16 için çeldirici grafiği

Tablo 10.'da madde 12'ye ait seçenek frekans tablosu görülmektedir. 12. madde için doğru seçenek D seçeneğidir ve 28 kişi tarafından tercih edilmiştir. Ancak B çeldiricisine bakıldığında, 86 kişi ile tüm seçeneklerden daha fazla tercih edildiği görülmektedir. 12. madde için $\mathrm{B}$ 
çeldiricisinin incelenmesi gerekmektedir. Çeldiricinin, doğru cevabın bir kısmını bünyesinde barındırmış olması ya da dilden kaynaklanan, yanlış anlaşılmaya müsait bir yapısının olması şeklinde bazı düzeltilebilir problemleri olabileceği gibi, seçenekler arasından çıartılmasına neden olacak düzeltilemez bir yapıs1 da olabilir.

Tablo 9.Madde 12 için seçenek frekans tablosu

\begin{tabular}{|c|c|c|c|c|c|c|}
\hline S12. Cevaplar & Kişi sayısı & Seçenlerin oranı & pBis & Ayırıcılık & Alt grup & Üst grup \\
& & & & & & \\
\hline A & 8 & 0.057971 & -0.2688 & -0.62500 & 0.625000 & 0 \\
\hline B & 86 & 0.623188 & -0.25912 & -0.10465 & 0.325581 & 0.22093 \\
\hline C & 16 & 0.115942 & -0.08428 & 0 & 0.187500 & 0.18750 \\
\hline D & 28 & 0.202899 & 0.043182 & 0.178571 & 0.178571 & 0.357143 \\
\hline
\end{tabular}

Şekil 6.'da doğru yanıt D seçeneğinin ve geri kalan üç çeldiricinin alt ve üst gruplarda değişen davranışları gösterilmektedir. Görüldüğü üzere, B çeldiricisinin alt ve üst gruplarda tercih edilme olasılıklarının doğru yanıt D seçeneğine kıyasla fazla olduğu söylenebilir. Bu durumda ölçme aracına dönülüp ilgili maddenin $B$ seçeneği incelenmelidir.

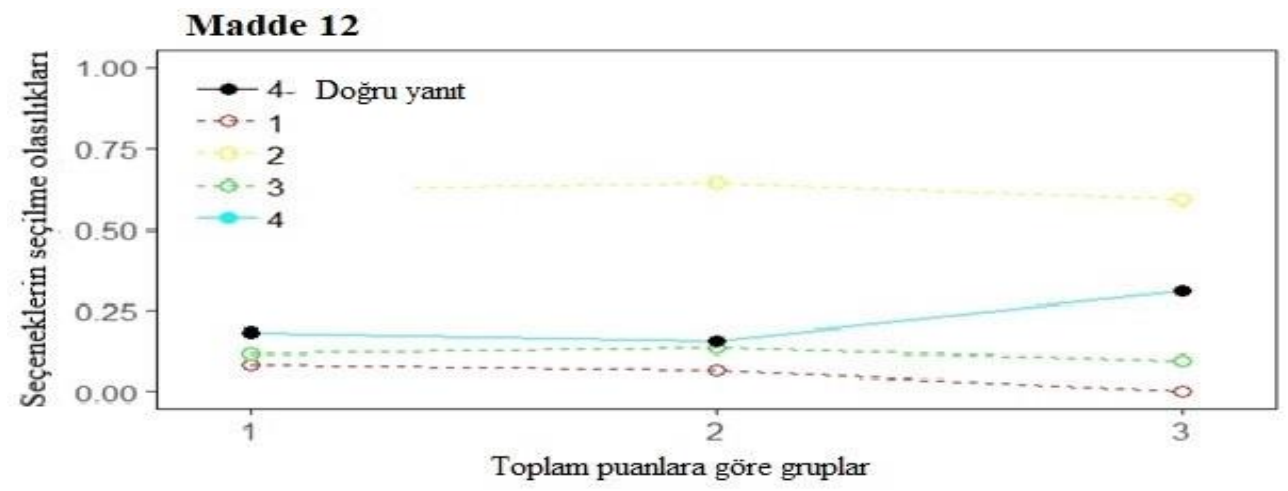

Şekil 6. Madde 12 için çeldirici grafiği

Tablo 11.'de madde 14 için seçenek frekans tablosu verilmiştir. Buradan 14. madde için doğru yanıt seçeneğinin $\mathrm{D}$ olduğu görülmektedir. D seçeneğini 43 kişi tercih etmiştir. Ancak diğer çeldirici seçeneklere bakıldığında A çeldiricisinin
63 kişi tarafindan seçilerek en çok tercih edilen seçenek olduğu görülmektedir. Buradan A seçeneğinin yapısal olarak incelenmesi gerektiğini söylemek mümkündür.

Tablo 10. Madde 14 için seçenek frekans tablosu

\begin{tabular}{|c|c|c|c|c|c|c|}
\hline $\begin{array}{c}\text { S14. } \\
\text { Cevaplar }\end{array}$ & Kişi sayısı & Seçenlerin oranı & pBis & Ayırıcılık & Alt grup & Üst grup \\
\hline A & 63 & 0.456522 & -0.21487 & -0.12698 & 0.317460 & 0.190476 \\
\hline B & 16 & 0.115942 & -0.12515 & 0.06250 & 0.250000 & 0.312500 \\
\hline C & 16 & 0.115942 & -0.30047 & -0.37500 & 0.500000 & 0.125000 \\
\hline D & 43 & 0.311594 & 0.007581 & 0.093023 & 0.209302 & 0.302326 \\
\hline
\end{tabular}

Şekil 7.'den görüldüğü üzere, A çeldiricisinin seçilme olasıllğının doğru yanıtla beraber diğer tüm seçeneklerden yüksek olduğunu söylemek mümkündür. Buradan A çeldiricisinin incelenmesi gerektiği sonucuna varılabilir. 


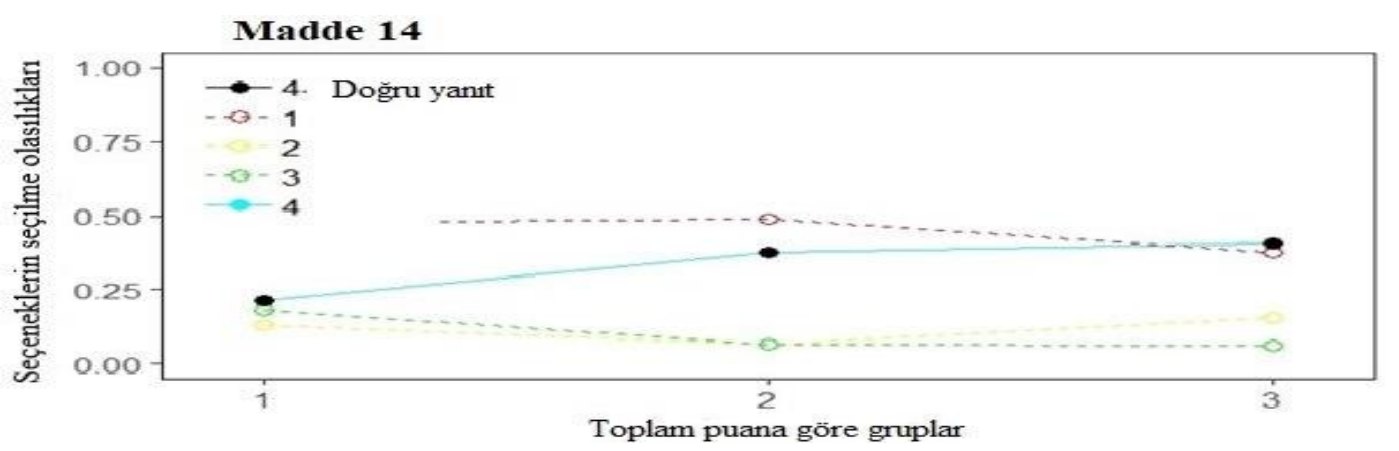

Şekil 7. Madde 14 için çeldirici grafiğgi

Tablo 12.'de 18. maddenin tüm seçenekleri için frekans dağılımı görülmektedir. İlgili maddenin doğru yanıtı D seçeneğidir. Doğru yanıt 23 kişi tarafindan tercih edilmiştir. Çeldiricilere bakıldığında ise, $C$ seçeneğinin 56 kişi ile en çok tercih edilen seçenek olduğu görülmektedir. C seçeneği, sadece çeldiriciler arasında değil, doğru yanıttan da fazla seçilen bir çeldiricidir. Aynı zamanda, $\mathrm{B}$ seçeneğinin, $\mathrm{C}$ den sonra en çok seçilen çeldirici olduğu Tablo 12.'den görülmektedir. Her iki çeldirici de doğru yanıttan fazla tercih edildiklerinden yapisal olarak incelenmeli, revize edilmeli hatta gerekirse ilgili maddeden çıkartılmalıdır.

Tablo 11. Madde 18 için seçenek frekans tablosu

\begin{tabular}{|c|c|c|c|c|c|c|}
\hline $\begin{array}{c}\text { S.18 } \\
\text { Cevaplar }\end{array}$ & Kişi sayısı & Seçenlerin oranı & pBis & Ayırıcılık & Alt grup & Üst grup \\
\hline A & 17 & 0.123188 & -0.04150 & 0.058824 & 0.294118 & 0.352941 \\
\hline B & 42 & 0.304348 & -0.30722 & -0.2142900 & 0.380952 & 0.166667 \\
\hline C & 56 & 0.405797 & -0.19595 & -0.1250000 & 0.321429 & 0.196429 \\
\hline D & 23 & 0.166667 & 0.00361 & 0.260870 & 0.086957 & 0.347826 \\
\hline
\end{tabular}

Şekil 8.'de 18. madde için seçenek grafiği görülmektedir. Grafikte, Tablo 12.'de belirtilen B ve $C$ çeldiricilerinin alt ve üst gruplardaki davranışları incelendiğinde, alt ve üst gruplarda, doğru yanıt seçeneğinden daha yüksek seçilme olasılıklarının olduğu görülmektedir. Buradan hareketle, ilgili maddenin $\mathrm{B}$ ve $\mathrm{C}$ seçeneklerinin yapisal olarak incelenmesi gerekmektedir, sonucuna ulaşmak mümkündür.

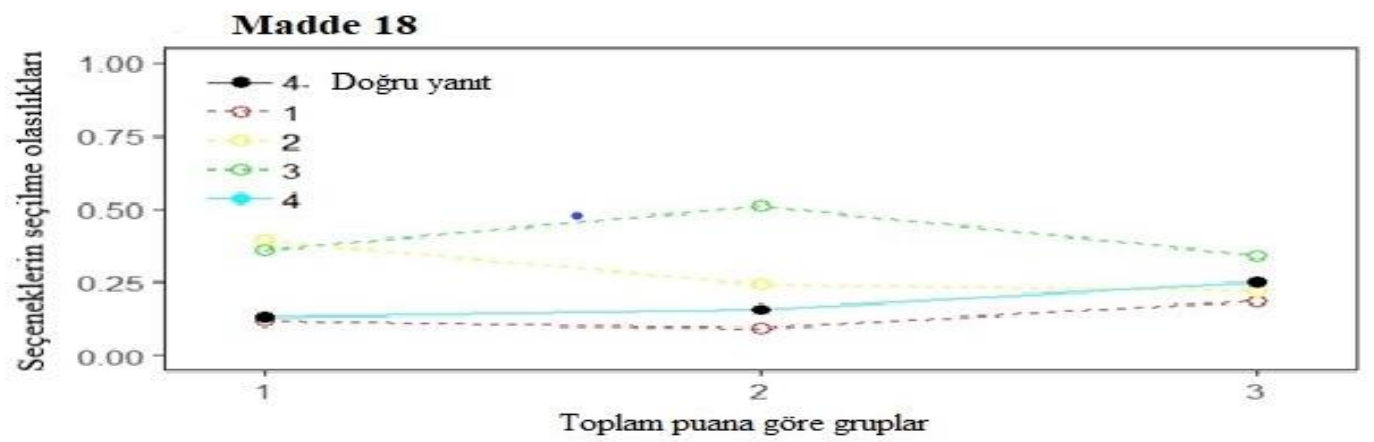

Şekil 8. Madde 18 için çeldirici grafiği

\section{Sonuçlar}

Çeldirici, çoktan seçmeli bir testte seçenekler arasında doğru yanıt dişındaki tüm yanıt seçenekleridir. Çeldirici analizi, ölçme aracı içindeki maddelerin kaliteleri ile ilgili bilgi sağlamak için kullanılan bir yöntemdir. Çeldirici analizi, güçlük ve ayırt edicilik indeksleri ile birlikte madde analizinin ayrılmaz bir parçasıdır.

Çalışmada İstatistiğe Giriş Okuryazarlık Testi bünyesindeki maddelere çeldirici seçenek analizi uygulanmıştır. Ölçme aracı kapsamında, çeldirici seçenek analizi bakımından iyi çeldiricilere sahip 
maddelerden ve çeldiricilerinin gözden geçirilmesi gereken bazı maddelerden örnekler verilmiştir. Örnek verilen maddeler çeldiricilerin davranışlarına göre seçilmiştir. Tüm maddeler için yapılan analiz sonrasında, en iyi maddeler ve en başarısız maddelerden seçim yapılmıştır. Analiz sonuçlarına göre elde edilen bilgilerden ilgili maddelerin çeldirici seçenekleri ile ilgili yorumlarda bulunulmuştur.

Analizlere başlamadan önce, tek ve çok değişkenli aykırı değer analizi yapılmış hesaplanan $\mathrm{z}$ değerleri ve Mahalanobis Uzaklıklarından hareketle veri setinde tek ya da çok değişkenli aykırı değere rastlanmamıştır.

Aykırı değer analizinin ardından Corrected ItemTotal Correlation değerleri hesaplanmıştır. Corrected Item- Total Correlation değeri en az 0.3 olmalıdır. 0.3'ün altındaki değerlerin ölçekten atılmas1 gerekmektedir. Tablo 3.'den kolaylıkla görüleceği gibi hiçbir maddenin Corrected ItemTotal Correlation değeri 0.3'ün altında değildir. Buradan, ölçekten madde atmaya gerek yoktur sonucuna varılabilir.

İç tutarlılığın değerlendirilmesinde alt ve üst grupların ortalamaları karşılaştırılmıştır. Tablo 4.'den bağımsız örnek $t$ testi için hesaplanan $p$ değerleri gözlemlendiğinde, tüm maddeler için anlamlılık düzeyi $0.05^{\prime}$ den küçüktür. Dolayısıyla, alt ve üst gruplar arasında fark yoktur şeklinde kurulan yokluk hipotezi reddedilir.

Ele alınan maddelerden ilki, 1. maddedir. İlgili maddenin seçenek frekans tablosu ile seçenek grafiği sirasiyla Tablo 6 . ve Şekil 2.'de gösterilmektedir. Tablo 6.'ya göre, madde 1'in doğru yanıtı $\mathrm{C}$ seçeneğidir ve 67 kişi tarafından tercih edilmiştir. Ayırıcılık ve nokta-biserial korelasyon değerleri beklendiği gibi pozitif, çeldiriciler için ise bu değerler negatiftir. Doğru yanıtı takip eden seçenekler seçilme sırasıyla 52 kişiyle B, 13 kişiyle D ve 6 kişiyle A'dır. Şekil 2.'ye bakıldığında doğru yanıt $C$ seçeneğinin alt gruptan üst gruba doğru gidildikçe seçilme olasılığının arttığı görülmektedir. Doğru yanıt seçeneğinden beklenen davranış bilen ile bilmeyen öğrenciyi ayırt edebilme gücüdür. C seçeneğinin bu özelliği, Şekil 2.'den gözlenen davranışı ile sağladığı görülmektedir. B seçeneğine bakıldığında ise alt gruptan üst gruba gidildikçe seçilme olasıllğının düştüğü görülmektedir. İyi bir çeldiricinin alt gruptan bireyleri kendine çekmesi beklenir. B seçeneği gözlemlenen davranışılla bu özelliği sağlamaktadır. Madde 1, bu özelliklerinden dolayı ölçme aracındaki kaliteli maddeler arasındadır.

Ele alınan diğer madde 5. maddedir. İlgili maddenin seçenek frekans tablosu ile seçenek grafiği sırasıyla Tablo 7. ve Şekil 3.'de gösterilmektedir. Tablo 7.'ye göre, madde 5'in doğru yanıtı $\mathrm{C}$ seçeneğidir ve 49 kişi tarafindan tercih edilmiştir. Ayırıcılık ve nokta-biserial korelasyon değerleri beklendiği gibi pozitif, çeldiriciler için ise bu değerler negatiftir. Doğru yanıtı takip eden seçenekler seçilme sırasıyla 43 kişiyle D, 35 kişiyle B ve 11 kişiyle A'dır. Şekil 3.'e bakıldığında doğru yanıt $\mathrm{C}$ seçeneğinin alt gruptan üst gruba gidildikçe seçilme olasılığının arttığı görülmektedir. $\mathrm{Bu}$, doğru yanıt için beklenen bir davranıştır. Doğru yanıtı en yakın takip eden D seçeneğinin de tam tersi bir davranış göstererek alt gruptan üst gruba doğru gidildikçe seçilme olasılı̆̆ının azaldığı görülmektedir. Buradan, D seçeneğinin bu madde için iyi bir çeldirici olduğunu söylemek mümkündür. Maddenin diğer çeldiricileri olan $B$ ve $A$ seçeneklerinin de çeldirici hareketlerine uygun davranışlar sergiledikleri Şekil 3.'den gözlenmektedir.

Madde 7 için seçenek davranışlarını Tablo 8. ve Şekil 4.'den görmek mümkündür. Tablo 8.'e göre 7. madde için doğru yanıt $B$ seçeneğidir ve 64 kişi tarafından tercih edilmiştir. Ayırıcılık ve noktabiserial korelasyon değerleri doğru yanıt seçeneği için pozitif, çeldiriciler için ise bu değerler negatiftir. İlgili maddenin tüm seçeneklerinin davranışlarını gözlemlemek için Şekil 4.'e bakıldığında doğru yanıt olan B seçeneğinin alt gruptan üst gruba doğru gidildikçe seçilme olasılığının arttığı görülmektedir. Çeldiricilerin davranışlarının ise, alt gruptan üst gruba gidildikçe, seçilme olasılığının azalması şeklinde olduğu görülmektedir. Bu sonuçlardan hareketle, 7. madde için ölçme aracına uygun bir madde olduğu söylenebilir.

Madde 16 için seçeneklerin göstermiş olduğu davranışlar Tablo 9. ve Şekil 5.'de görüldüğü gibidir. Tablo 9.'a göre, maddenin doğru yanıtı D seçeneğidir ve 38 kişi tarafından tercih edilmiştir. Ayırıcılık indeksi ve nokta-biserial korelasyon değerlerinin pozitif olduğu tablodan görülmektedir. Çeldiricilerden $\mathrm{B}$ seçeneğinin de 38 kişi tarafından tercih edildiği tablodan gözlemlenebilir. $\mathrm{Bu}$ durumda, öncelikle, tablodan ayırıcılık indeksi ve nokta-biserial değerlerine bakılmalıdır. Çeldiriciler için bu değerlerin negatif olması beklenir. Tablo 9.'a bakıldığında bu değerlerin negatif olduğu görülmektedir. 
Seçeneklerin alt ve üst gruplardaki davranışlarını belirlemek için ise Şekil 5.'e bakılmalıdır. Doğru yanıt olan D seçeneğinin seçilme olasılığının alt gruptan üst gruba gidildikçe arttı̆̆ı görülmektedir. Aynı sayıda kişi tarafından tercih edilen B seçeneğinin ise, tam tersi bir davranış sergilediğini görmek mümkündür. $\mathrm{Bu}$ anlamda çeldirici ve doğru yanıt hareketlerinde bir problem olmadığ1 sonucuna varılır. Aynı zamanda Tablo 9.'dan B ve D seçeneklerinin alt ve üst gruplarda seçilme oranlarını da görmek mümkündür. Buradan, çeldiriciler için seçilme oranlarının alt gruptan fazlayken, üst gruptan az, doğru yanıt için seçilme oranlarının ise, üst grupta fazlayken, alt grupta az olduğu söylenebilir.

Madde 12 için seçeneklerin alt ve üst gruplardaki davranışları Tablo 10. ve Şekil 6.'da verilmiştir. Tablo 10.'a bakıldığında, maddenin doğru yanıtının D seçeneği olduğunu ve 28 kişi tarafından işaretlendiğini görmek mümkündür. Ayırıcılık indeksi değerleri ve nokta-biserial korelasyon değerleri doğru yanıt için pozitif, yanlış yanıt için ise negatifdir. Ancak, B seçeneği 86 kişi ile doğru yanıttan daha fazla tercih edilmiştir. Alt ve üst gruplardaki seçilme oranlarına bakıldığında ise, çeldirici ve doğru yanıt davranışlarına uygun olmayan bir oran olmadığ görülebilir. Şekil 6.'ya bakıldığında, B seçeneğinin alt ve üst gruplarda doğru yanıt dahil tüm seçeneklerden fazla tercih edilme olasılı̆̆ına sahip olduğu görülmektedir. Bu durumda madde ve seçenekler incelenmelidir. 12 . madde incelendiğinde, $\mathrm{B}$ ve $\mathrm{D}$ seçeneklerinin ters matematiksel operatörlerden oluştuğu görülür. B seçeneğinin yüksek frekansa sahip olma sebebi için, matematiksel operatörlerin birbiriyle karıştırılmasından kaynaklanan bir hata olduğu söylenebilir.

Madde 14 için seçeneklerin davranışları Tablo 11. ve Şekil 7.'de gösterilmiştir. Tablo 1.'e bakıldığında, maddenin doğru yanıtının D seçeneği olduğu ve 43 kişi tarafindan seçildiği görülmektedir. Ayırıcılık indeksi değerleri ve nokta-biserial korelasyon değerleri, doğru yanıt için pozitif, yanlış yanıt için negatifdir. Ancak, A seçeneğinin 63 kişi ile doğru yanıttan fazla tercih edildiği tablodan gözlemlenmektedir. Şekil 7.'ye bakıldığında, D seçeneğinin, üst gruba doğru seçilme olasılığının arttığı görülmesine rağmen, A seçeneğinin de üst grupta seçilme olasılığının doğru yanıta oldukça yakın olduğu görülmektedir. Ek'den 14. maddeye bakıldığında, madde kökünde, A kümesinden yazılacak 4 basamaklı sayıların birbirinden farklı olup olmadıkları ifadesine yer verilmediği görülmektedir. Bu ifade eksikliğinden kaynaklı hata sebebiyle, öğrencilerin doğru yanıttan uzaklaştıkları söylenebilir.

Madde 18 için doğru yanıt ve çeldiricilerin davranışları Tablo 12. ve Şekil 8.'de görülmektedir. Tablo 12.'ye göre, maddenin doğru yanıtı $\mathrm{D}$ seçeneğidir ve 23 kişi tarafindan işaretlenmiştir. Ayırıcılık indeksi değerleri ve nokta-biserial korelasyon değerleri doğru yanıt için pozitif, yanlış yanıt için negatifdir. Ancak, B seçeneği 42 ve $C$ seçeneği 56 kişi ile doğru yanıttan fazla işaretlenmiştir. Şekil 8.'e bakıldığında ise, $\mathrm{B}$ ve $\mathrm{C}$ seçeneklerinin seçilme olasılıklarının daha fazla olduğu görülmektedir. Ek'den 18. maddeye bakıldığında, 4 erkek ve 5 kız öğrenci arasından en az biri erkek olmak üzere kurulabilecek 3 kişilik grupların sayısı istenmektedir. Ölçme aracı hazırlanırken, madde kökünde istenen özelliğin vurgulanması gerekmektedir. Örneğin; aşağıdakilerden hangisi yanlıştır şeklinde kurulan bir madde kökünde, yanlıştır kelimesi vurgulanmalıdır. Bu madde için istenen en az biri erkek ifadesi vurgulanmadığından öğrenciler tarafindan dikkatsizlikle gözden kaçtığ 1 , bunun sonucunda da öğrencilerin çeldirici seçeneklere yöneldiği söylenebilir.

$\mathrm{Bu}$ çalışmada İstatistiğe Giriş Okuryazarlık Testine çeldirici analizi yapılmıştır. İlerleyen çalışmalar için Okuryazarlık testi Değişen Çeldirici Fonksiyonu (DÇF) açısından incelenebilir. DÇF, çeldiricilerin yanlı olup olmadiklarını yanlı ise hangi alt gruba avantaj ya da dezavantaj sağlandığının belirlenmesinde kullanılan bir yöntemdir. Ayrıca, ulusal ya da uluslararası yapılan geniş ölçekli çoktan seçmeli sinavlar için, örneğin; PISA, TIMMS ya da ÖSYM sınavları gibi, çeldirici analizleri yapilabilir.

\section{Kaynaklar}

Alagumalai, S. and Keeves, J.P.,1999. DistractorsCan They Be Biased too? Journal of Outcome Measurement, 3(1), 89-102.

Allen, D. D., 2012. Validity and Reliability of the Movement Ability Measue: A Self-Report Instrument Proposed for Assessing Movement Across Diagnoses and Ability Levels. Physical Thearapy, 87(7), 899-916.

Attali, Y. and Fraenkel, T., 2000. The Point-Biserial As A Discrimination Index for Distractors in Multiple-Choice Items: Deficiencies in Usage and An Alternative. Journal of Educational Measurement, 37(1), 77-86. 
Baykul, Y., 2000. Eğitimde ve Psikolojide Ölçme: Klasik Test Teorisi ve Uygulaması. ÖSYM Yayınları, Ankara, 504s.

Cristobal, E., Flavian, C. and Guinaliu, M., 2007. Perceived E-service Quality (PeSQ): Measurement Validation and Effects on Consumer Satisfiction and Web Site Loyalty, Journal of Service Theory and Practice, 17(3), 317-340.

De Grutijter, D. N. and Van der Kamp, L. J., 2008. Statistical Test Theory for the Behavioral Sciences. Chapman\&Hall, London, 280p.

DeVellis, R. F., 2006. Quantitative and Issues and Approaches: Classical Test Theory (CTT) and Item Response Theory (IRT). Medical Care, 44(11), 50-59.

Flanagan, J. C., 1952. The effectiveness of short methods for calculating correlation coefficients. Psychological Bulletin, 49(4), 342348.

Gajjar, S., Sharma, R., Kumar, P. and Rana, M., 2014. Item and Test Analysis to Identify Quality Multiple Choice (MCQs) from An Assessment of Medical Students of Ahmedabad, Gujarat. Indian Journal of Community Medicine, 39(1), 17-20.

Gierl, N.J., Bulut, O., Guo, Q. and Zhang, X., 2017. Developoing, Analyzing and Using Distractors for Multiple-Choice Tests in Education: A Comprehensive Review. Review of Educational Research, 87(6), 1082-1116.

Güler, N., 2008. Klasik Test Kuramı Genellenebilirlik Kuramı ve Rasch Modeli Üzerine Bir Araştırma. Doktora Tezi, Hacettepe Üniversitesi Sosyal Bilimler Enstitüsü, Ankara, 135s.

Haladyna, T. M. and Downing, S. M., 1993. How Many Options is Enough for A Multiple-Choice Item? Educational and Psychological Measurement, 53(4), 999-1010.

Haladyna, T. M., 2016. Item Analysis for SelectedResponse Test Items. Handbook of Test Development. Lane, S., Raymond, M. and Haladyna, T. (Eds.), NY: Routledge, New York. pp.392-409.

Hambleton, R. and Jirka, S., 2006. Anchor-Based Methods for Judgmentally Estimating Item Statistics. Handbook of Test Development. Downing, S. and Haladyna, T. (Eds.), NJ: Erlbaum, Mahwah. pp. 399-420.
Hingorjo, M.R. and Jaleel, F., 2012. Analysis of OneBest MCQs: The Difficulty, Discrimination Index and Discrimination Efficiency, Journal of Pakistan Medical Association, 62(2), 142-147.

Kelly, F.J., 1914. Teacher's Marks: Their Variability and Standardization. Colombia University, New York, 160p.

Kelly, F.J.,1916. The Kansas Silent Reading Tests. The Journal of Educational Psychology, 7(2), 62-80.

Schmitt, A.P. and Dorans, N.J.,1990. Differential Item Functioning for Minority Examinees on the SAT, Journal of Educational Measurement, 27(1), 67-81.

Stalnaker, J. M. and Stalnaker, R. C., 1935. Chance vs. Selected Distractors in a Vocabulary Test. Journal of Educational Psychology, 26(3), 161-168.

Şencan, H., 2005. Sosyal ve Davranışsal Ölçümlerde Güvenilirlik ve Geçerlilik. Seçkin Yayıncılık, Ankara, 865s.

Tekin, H. 1977. Eğitimde Ölçme ve Değerlendirme. Mars Matbaası, Ankara, 328s.

Thissen, D., Steinberg, L., and Fitzpatrick, A.R.,1989. Multiple-Choice Models: The Distractors Are Also Part of the Item, Journal of Educational Measurement, 26(2), 161-176.

Tomak,L., 2013. Madde Analizi ve Tıp Fakültesi Sınavlarının Değerlendirilmesi, Doktora Tezi, Ondokuz Mayis Üniversitesi Fen Bilimleri Enstitüsü. Samsun, 157s.

Turgut, M.F., 1977. Eğitimde Ölçme Teknikleri. Nüve Matbaası, Ankara.

Uyar, Ş. ve Doğan, N., 2014. P1sa 2009 türkiye örnekleminde öğrenme stratejileri modelinin farklı gruplarda ölçme değişmezliğinin incelenmesi, International Journal of Turkish Education Science, 2014(3), 30-43.

Wang, W.C., 1998. Rasch Analysis of Distractors in Multiple-Choice Items. Journal of Outcome Measurement, 2(1), 43-65.

Wind, S.A., Alemdar, M., Lingle, J.A., Moore, R. and Asilkalkan, A., 2019. Exploring Student Understanding of the Engineering Design Process Using Distractor Analysis, Journal of STEM Education, 6(4). 


\section{EK 1.}

Cinsiyet:

Bölüm:

\section{İSTATISSTİĞE GİRIŞ OKURYAZARLIK TESTI}

1. Aşağıdakilerden hangisi sürekli değişkenlere örnek olarak verilebilir?

a) Bir sinifin mevcudu

b) Bir ilin nüfusu

c) Gelir düzeyi

d) Çocuk sayısı

2. Kitleyi temsil etmek için örneklemden hesaplanan değerlere ne ad verilir?
a) Örneklem
b) Parametre
c) İstatistik
d) Anakütle

3. Aşağıdakilerden hangisi nicel veriye örnek olarak verilebilir?
a) Cinsiyet
b) Eğitim durumu
c) Göz rengi
d) Boy

4. Herhangi bir veri kümesindeki elemanların ortalamadan sapmalarının karelerinin toplamının veri sayısına bölümü aşağıdaki kavramlardan hangisi ile ifade edilebilir?
a) Standart hata
b) Değişim katsayısı
c) Standart sapma
d) Varyans

5. $\quad \mathrm{N}$ tane nesnenin tümünün veya bir kısmının tekrar olmaksızın sıralanması işlemine ne ad verilir?
a) Cebir
b) Olasilik
c) Permütasyon
d) Kombinasyon

6. Aşağıdakilerden hangisi kesikli rastgele değişkene örnektir?
a) Kişinin ağırlığ
b) Bir sorunun çözülme süresi
c) Madeni paranın 3 kere atılması deneyinde yazı gelme sayıs1
d) Bir arsanın fiyatı

7. Bir deney sonucundaki tüm mümkün sonuçlar kümesine ne denir?
a) Olay
b) Örnek uzay

c) Örneklem

d) Olasillk

8. İki olaydan birinin gerçekleşmesi diğerinin gerçekleşmesini etkilemiyorsa bu tür olaylar için aşağıdakilerden hangisi söylenebilir?
a) Bağımlı olay
b) Rastgele deney
c) Bağımsız olay
d) Ayrik olay

9. Kitle veya örnek birimlerinden belirli değişkenler için çeşitli ölçme düzeylerine göre alınan ölçüm sonuçlarının oluşturduğu küme aşağıdakilerden hangisidir?
a) Parametre
b) Denek
c) Veri
d) Olasilik
e)

10. Aşağıdakilerden hangisi nitel veriler için çizilebilecek grafiklerdendir?
a) Yığılımlı sıklık
b) Dağılım poligonu
c) Dal ve yaprak gösterimi
d) Daire dilimi grafiğ $i$

11. Aşağıdakilerden hangisi nicel veriler için kullanılabilecek bir konum ölçüsüdür?
a) Ortalama
b) Standart sapma
c) Dağılım genişliği
d) Varyans

12. Ortalamalar için yazılan eşitliklerden hangisi doğrudur?
a) G. $\mathrm{O} .=\mathrm{A} . \mathrm{O} . \leq \mathrm{H} . \mathrm{O}$.
b) A..$\leq$ G. O. $\leq$ H. O.
c) A. $0 . \leq$ H. $0 .=$ G. 0 .
d) A. $0 . \geq$ G. O. $\geq$ H. 0 .

13. A kentinden $B$ kentine 4 , $B$ kentinden $C$ kentine 5 farklı yol bulunmaktadır. Buna göre, A kentinden $\mathrm{C}$ kentine, $\mathrm{B}$ kentine uğramak koşulu ile kaç farklı yoldan gidilebilir?
a) 16
b) 18
c) 20
d) 25

14. $A=\{1,2,3,4,5\}$ kümesinin elemanları kullanılarak 4 basamaklı kaç doğal sayı yazılabilir?
a) 120 

b) 255
c) 400
d) 625

15. $A=\{1,2,3,4,5,6,7\}$ kümesinin elemanlarını kullanarak rakamları farklı 3 basamaklı kaç farklı çift sayı yazılabilir?
a) 70
b) 84
c) 90
d) 98

16. $A=\{1,2,3,4,5,6\}$ kümesinin elemanlar1 ile rakamları farklı 3 basamaklı 300'den büyük kaç doğal sayı yazılabilir?
a) 36
b) 45
c) 60
d) 80

17. 5 elemanlı bir kümenin en az 2 elemanlı alt kümelerinin sayısı kaçtır?
a) 20
b) 26
c) 30
d) 45

18. 4 erkek ve $5 \mathrm{kiz}$ öğrenci arasından en az biri erkek olmak üzere 3 kişilik kaç farklı grup kurulabilir?
a) 44
b) 54
c) 64
d) 74

19.

$\underset{\text { Şekildeki } 7 \text { noktadan kaç doğru geçer? }}{\stackrel{*}{\longrightarrow} * * \quad *}$
a) 14
b) 22
c) 24
d) 30

20. Aşağıdakilerden hangisi eşit aralıklı ölçme düzeyinde ölçülen bir değişkendir?
a) Santigrat cinsinden y1llik ortalama hava sıcaklığı
b) Eğitim durumu
c) Cinsiyet
d) Tedavide kullanılan ilaç türü

21. Bir işyerinde çalışan büyük bir grubun aylı gelir ortalamas1 1000 TL ve standart sapmas1 100 TL'dir. Bu grupta geliri $1200 \mathrm{TL}$ olan bir çalışanın $\mathrm{Z}$ değeri aşağıdakilerden hangisidir?
a) -2
b) 2
c) -1
d) 1

22. Bir normal dağılım eğrisinin sağa çarpık olması durumunda aşağıdakilerden hangisinin doğru olduğu söylenebilir?
a) Mod $=$ Medyan $=\overline{\mathrm{X}}$
b) Mod $<$ Medyan $<\bar{X}$
c) Mod $>$ Medyan $>\bar{X}$
d) $\operatorname{Mod}=$ Medyan $>\bar{X}$

23. Bir standart normal dağılımın aşağıdaki özelliklerden hangisini sağlaması beklenir?
a) $\mu=0, \sigma=1$, Çarpıklık $=0$, Basıklık $=3$
b) $\mu=0, \sigma=1$, Çarpıklık $=3$, Basıklık $=3$
c) $\mu=1, \sigma=1$, Çarpıklık $=0$, Basıklık $=3$
d) $\mu=0, \sigma=1$, Çarpıklık $=3$, Basıklık $=0$

24. Aşağıdaki grafiklerden hangisi simetrik bir dağılımı gösterir?

a

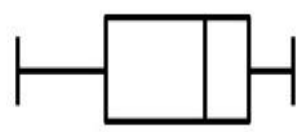

b)

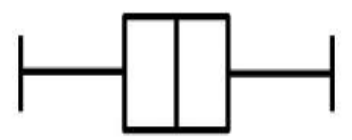

c)

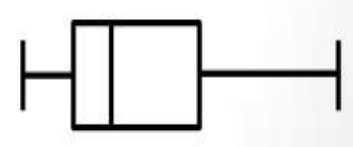

d)

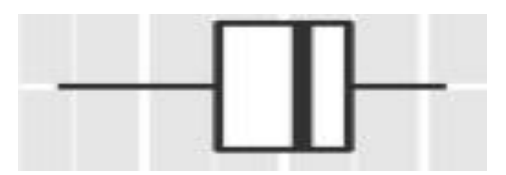

25.

\begin{tabular}{|l|l|l|l|l|}
\hline$Z$ & 0 & 0,01 & 0,02 & 0,03 \\
\hline 1,0 & 0.3413 & 0,3438 & 0,3461 & 0,3485 \\
\hline 1,1 & 0,3643 & 0,3665 & 0,3686 & 0,3708 \\
\hline 1,2 & 0,3849 & 0,3869 & 0,3888 & 0,3907 \\
\hline 1,3 & 0,4032 & 0,4049 & 0,4066 & 0,4082 \\
\hline 1,4 & 0,4192 & 0,4207 & 0,4222 & 0,4236 \\
\hline
\end{tabular}

Yukarıda $\mathrm{Z}$ tablosunun bir kesiti verilmiştir. $\mathrm{Bu}$ tabloya göre $P(Z \leq-1.32)$ değeri aşağıdakilerden hangisidir?
a) 0,0934
b) 0,0926
c) 0,0912
d) 0,0955 